Barbara Letícia Rosa Pereira

Carlos Eduardo Coradassi

Carolina Ribeiro Duarte

Caroline Soczek da Silva

Denise Damo Comel

Erildo Vicente Muller

Estela Baldani Pinto

Fabiana Postiglione Mansani

Felício de Freitas Netto

Gabriela Benassi
Hélcio dos Santos Pinto Jorge Felipe do Lago Pereira dos Santos Lara Simone Messias Floriano

Lislei Terezinha Preuss

Lorena Slusarz Nogueira Maria Cleonice Alves de Oliveira

Maria Dagmar da Rocha

Mauriceia Ribeiro de Souza

Mateus Alves dos Santos

Pollyanna Kássia de Oliveira Borges

Ricardo Zanetti Gomes

\title{
MANEJO DE CORPOS EM SUSPEITOS OU CONFIRMADOS COVID-19: UM APOIO AOS MUNICÍPIOS EM CASO DE ÓBITO
}




\title{
UNIVERSIDADE ESTADUAL DE PONTA GROSSA
}

\author{
Reitor \\ Miguel Sanches Neto \\ Vice-reitor \\ Everson Augusto Krum
}

Pró-reitora de Extensão e Assuntos Culturais

Edina Schimanski 
Barbara Letícia Rosa Pereira

Carlos Eduardo Coradassi

Carolina Ribeiro Duarte

Caroline Soczek da Silva

Denise Damo Comel

Erildo Vicente Muller

Estela Baldani Pinto

Fabiana Postiglione Mansani

Felício de Freitas Netto

Gabriela Benassi
Hélcio dos Santos Pinto

Jorge Felipe do Lago Pereira dos Santos

Lara Simone Messias Floriano

Lislei Terezinha Preuss

Lorena Slusarz Nogueira

Maria Cleonice Alves de Oliveira

Maria Dagmar da Rocha

Mauriceia Ribeiro de Souza

Mateus Alves dos Santos

Pollyanna Kássia de Oliveira Borges

Ricardo Zanetti Gomes

\section{MANEJO DE CORPOS EM \\ SUSPEITOS OU CONFIRMADOS \\ COVID-19: UM APOIO AOS MUNICÍPIOS EM CASO DE ÓBITO}

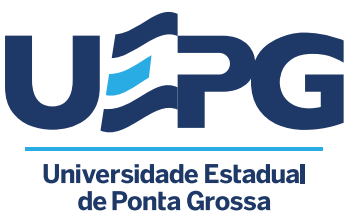




\title{
PROEX UEPG
}

\section{Equipe editorial}

\section{Revisão de língua portuguesa \\ Emilson Werner}

\section{Ilustradores}

Ana Fernanda Fagundes Gonçalves, Gabriela Benassi, Jorge Felipe do Lago Pereira dos Santos, Larissa Guil e Lorena Slusarz Nogueira

\author{
Diagramação \\ Andressa Marcondes
}

Apoio

Editora UEPG

M274 Manejo de corpos em suspeitos ou confirmados COVID-19: um apoio aos municípios em caso de óbitos (livro eletronico]/ Barbara Letícia Rosa Pereira et al. Ponta Grossa: UEPG/PROEX, 2021.

67p.; il.; E-book - PDF

ISBN: 978-65-86967-23-4

DOI: 10.5212/86967-23-4

1. COVID-19- Prevenção. 2. Óbito - procedimentos. 3. Óbito - orientação. I. Pereira, Bárbara Letícia Rosa et al. II. T.

CDD: 618.2

Ficha Catalográfica elaborada por Maria Luzia Fernandes Bertholino dos Santos - CRB9/986 


\section{SUMÁRIO}

APRESENTAÇÃO

ORIENTAÇÕES GERAIS PÓS-ÓBITO

MANEJO DE CORPOS NO CONTEXTO DA COVID-19

OCORRÊNCIA DOMICILIAR E INSTITUIÇÃO DE MORADIA 16

QUANDO O ÓBITO OCORRER EM ESPAÇO PÚBLICO 20

RECOMENDAÇÕES PARA COLETA DE TECIDOS

E MANIPULAÇÃO DE AMOSTRAS

EMISSÃO DE DECLARAÇÃO DE ÓBITO. 26

PROCEDIMENTO OPERACIONAL PADRÃO PARA IDENTIFICAÇÃO, MANEJO E TRANSPORTE PÓS-ÓBITOS POR COVID-19 33

O REGISTRO (ASSENTO) DE ÓBITO NAS SERVENTIAS DE REGISTRO CIVIL DAS PESSOAS NATURAIS

DISCUSSÕES SOBRE ÓBITOS NA PANDEMIA COVID-19:

ESTRATÉGIAS DE ENFRENTAMENTO E CUIDADO DE FAMILIARES E PROFISSIONAIS DE SAÚDE. 


\section{LISTA DE FIGURAS}

Figura 1 -- Diluição de solução clorada a 0,1\% e 0,5\% para desinfecção de superfícies.

Figura 2 -- Ficha de notificação COVID-19 (primeira página) do Estado do Paraná.

Figura 3 -- Meio de transporte viral para inserção de material biológico para análise laboratorial de suspeita COVID-19

Figura 4 -- Caixa refrigerada com gelo reutilizável e recipiente para transporte de material biológico.

Figura 5 -- Exemplo de preenchimento das causas de óbito por COVID-19, com associação de comorbidades crônicas.

Figura 6 -- Exemplo de preenchimento das causas de óbito em suspeitos COVID-19.

Figura 7 -- Precauções em caso de funerais de suspeitos COVID

Figura 8 -- Cuidados em relação ao manejo de corpos no ambiente hospitalar.

Figura 9 -- Reconhecimento por familiar/responsável.

Figura 10 - Embalagem do corpo no local de óbito

Figura 11 - Identificação do corpo

Figura 12 - Sequência de transporte do corpo

Figura 13 - Ementa da Portaria Conjunta N² de 28 de abril de 2020 do Conselho Nacional de Justiça e do Ministério da Saúde.

Figura 14 - Comunicação entre profissionais de saúde, familiares e paciente com COVID-19.

Figura 15 - Modelo de comunicação virtual de óbitos.

Figura 16 - Fluxograma de acompanhamento e atendimento por profissionais da saúde para paciente com COVID-19 e seus familiares 


\section{APRESENTAÇÃO}

Fabiana Postiglione Mansani

Lislei Terezinha Preuss

Este Manual é resultado de uma das ações realizadas pelo Projeto de Extensão denominado Programa UEPG de Apoio Institucional para Ações Extensionistas de Prevenção, Cuidados e Combate à Pandemia do Novo Coronavírus, desenvolvido pela Universidade Estadual de Ponta Grossa e Fundação Araucária do Estado do Paraná, junto às regionais de saúde. Esta ação relaciona-se especificamente à $3^{\text {a }}$ Regional de Saúde do Estado do Paraná, que abrange onze municípios: Arapoti, Carambeí, Castro, Ipiranga, Ivaí, Jaguariaíva, Palmeira, Piraí do Sul, Porto Amazonas, São João do Triunfo e Sengés.

A Organização Mundial da Saúde (2020), em 11 de março de 2020, passou a caracterizar a COVID-19 como uma pandemia, devido ao rápido crescimento do número de casos confirmados e de mortes em decorrência da doença em diferentes países. A pandemia causada pelo novo coronavírus impõe desafios diários, especialmente aos profissionais da área da saúde, como no que se refere ao manejo de corpos nos casos de óbitos.

Os óbitos por COVID-19 têm ocorrido não somente em hospitais, mas também nos domicílios. É frente a esse cenário que o Manual foi elaborado com o objetivo de orientar o manejo de corpos no contexto da COVID-19. Para tanto, foram sistematizadas informações e orientações de fácil compreensão para os profissionais da área da saúde.

Neste cenário, as necessidades espirituais nem sempre podem ser atendidas. Velórios e enterros foram reconfigurados durante a pandemia: são proibidos ou realizados com restrições para diminuir as chances de contágio. De acordo com as orientações da Vigilância Sanitária, procedimentos como tanatopraxia não são recomendáveis, devido ao alto risco de transmissão póstuma da COVID-19; os falecidos 
em decorrência da COVID-19 devem ser cremados ou acomodados em caixão lacrado, o que impede a aproximação, contato e visualização do corpo pela família (BRASIL, 2020). As medidas de distanciamento social adotadas dificultam o apoio social e o conforto aos familiares e pessoas próximas que perderam seus entes queridos, causando repercussões no processo e vivência de luto.

Diante disso, intervenções alinhadas pelos profissionais que estão na linha de frente, pautadas na ética, são de suma importância. As famílias devem ser informadas e orientadas de maneira cuidadosa e sensível sobre os procedimentos necessários; elas precisam ter a oportunidade para esclarecer dúvidas e tomar decisões relativas ao falecido (SSHAP, 2020 apud CREPALDI; NOALI; BOLZE; GABARRA, 2020).

Nas várias situações de óbitos de pacientes por COVID-19, confirmados ou suspeitos, como é o caso dos óbitos ocorridos no domicílio ou em espaço público, elencaram-se neste Manual as medidas de precaução para evitar contaminação dos profissionais. Abordam-se, também, as temáticas: manipulação, processamento e análise de amostras biológicas e teciduais em tempos de pandemia da COVID-19, que exigem as precauções de rotina somadas às especificidades da situação. Buscase reforçar a importância da Emissão de Declaração de Óbito, com propósito de orientação sobre o preenchimento correto, no contexto da COVID-19. Por fim, o Manual traz uma abordagem psicológica sobre a vivência do luto em período de pandemia.

\section{Referências bibliográficas}

BRASIL. Ministério da Saúde. Manejo de corpos no contexto do novo coronavírus COVID-19. In: Manejo de corpos no contexto do novo coronavírus COVID-19. 25 mar. 2020. Disponível em: https:// portalarquivos.saude.gov.br/images/pdf/2020/marco/25/manejocorpos-coronavirus-versao1-25mar20-rev5.pdf. Acesso em: 20 jun. 2020.

CREPALDI, M. A., SCHMIDT, B., NOALl, D. S., BOLZE, S. D. A., \& GABARRA, L. M. (2020). Terminalidade, morte e luto na pandemia de COVID-19: demandas psicológicas emergentes e implicações práticas. Estudos de Psicologia (Campinas), 37, e200090. https://doi.org/ 10.1590/1982-0275202037e200090 


\section{ORIENTAÇÕES GERAIS PÓS-ÓBITO}

\section{Erildo Vicente Muller Mateus Alves dos Santos}

Em dezembro de 2019, em Wuhan, China, um novo coronavírus (SARS-CoV-2) foi identificado como causa de doença respiratória aguda grave (COVID-19). Em janeiro de 2020, a Organização Mundial da Saúde (OMS) declarou o surto como uma emergência de saúde pública de interesse internacional e, em março do mesmo ano, com a disseminação do vírus em diferentes países, foi declarada a pandemia.

Os sintomas mais comuns são: febre, tosse seca e dificuldade para respirar, os quais aparecem gradualmente e geralmente são leves. A transmissão costuma ocorrer no contato com infectados, por meio de secreções, como gotículas de saliva, e por meio de fômites, com o vírus podendo permanecer viável em superfícies ambientais por 24 horas ou mais.

A transmissão de doenças infecciosas também pode ocorrer por meio do manejo de corpos, sobretudo em equipamentos de saúde. Esse risco é agravado por uma situação de ausência ou uso inadequado dos equipamentos de proteção individual (EPIs), o que expõe os profissionais envolvidos com os cuidados com corpos ao risco de infecção.

Os velórios e funerais de pacientes confirmados ou suspeitos da COVID-19 não são recomendados, para evitar-se a aglomeração de pessoas em ambientes fechados. Nesse caso, o risco de transmissão também está associado ao contato entre familiares e amigos. A autópsia também não deve ser realizada e é desnecessária, em caso de confirmação de COVID-19 anterior à morte.

Os procedimentos pós-óbito devem ser realizados ainda no quarto de isolamento na unidade de atendimento, com porta fechada e feitos pelo menor número possível de profissionais, os quais devem portar: gorro, óculos de proteção ou protetor facial, máscara cirúrgica, avental 
impermeável e luvas. Caso seja necessário realizar procedimentos que geram aerossol, como extubação, usar máscara N95, PFF2 ou equivalente.

Devido ao risco aumentado de complicações em prognósticos da COVID-19, recomenda-se que profissionais com idade igual ou superior a 60 anos, gestantes, lactantes e portadores de doenças crônicas, cardiopulmonares, oncológicas ou imunodeprimidos não realizem atividades relacionadas ao manejo de corpos de casos confirmados ou suspeitos da doença. Se for possível o monitoramento, recomenda-se que sejam registrados nomes, datas e atividades de todos os trabalhadores que participaram dos cuidados, incluindo limpeza do quarto ou enfermaria.

É recomendado que a comunicação do óbito seja feita aos familiares, amigos e responsáveis preferencialmente pela equipe da atenção psicossocial ou assistência social, incluindo o auxílio para a comunicação sobre os procedimentos referentes à despedida da pessoa a eles afetivamente relacionada.

Os princípios das precauções-padrão de controle de infecções e precauções contra a transmissão devem continuar sendo aplicados no manuseio do corpo. Isso ocorre devido ao risco contínuo de transmissão infecciosa por contato, embora o risco seja geralmente menor que os relacionados aos pacientes ainda vivos.

\section{Referências bibliográficas}

PARANÁ. Secretaria Estadual de Saúde. Nota orientativa n.19 de 2020. Recomendações gerais para manejo de óbitos suspeitos e confirmados por COVID-19 no estado do Paraná. Disponível em: https://www.saude.pr.gov.br/sites/default/arquivos_restritos/files/ documento/2020-06/no_19_manejo_de_obitos_suspeitos_e_ confirmados_por_doenca_por_covid_19_v2.pdf> Acesso em: $16 \mathrm{dez}$ 2020.

BRASIL. Ministério da Saúde. Manejo de corpos no contexto do novo coronavírus COVID-19. In: Manejo de corpos no contexto do novo coronavírus COVID-19. 25 mar. 2020. Disponível em: https:// portalarquivos.saude.gov.br/images/pdf/2020/marco/25/manejocorpos-coronavirus-versao1-25mar20-rev5.pdf. Acesso em: 20 jun. 2020 . 


\section{MANEJO DE CORPOS NO CONTEXTO DA COVID-19}

Como o vírus SARS-CoV-2 é transmitido pelo contato interpessoal e por meio de fômites, é indispensável que todos os profissionais envolvidos no manejo de corpos estejam protegidos da exposição a sangue e fluidos corporais infectados utilizando, para isso, EPIs.

São eles:

- Gorro;

- Óculos de proteção ou protetor facial;

- Avental impermeável de manga longa;

- Máscara cirúrgica.

- Caso seja necessária a realização de procedimentos que gerem aerossóis, como extubação ou coleta de amostras respiratórias, usar máscaras N95, PFF2 ou equivalente.

- Luvas nitrílicas durante todo o procedimento;

- Botas impermeáveis e propé.

*As luvas de borracha nitrílica são um tipo de luva descartável feito de borracha sintética. 


\section{Considerações gerais sobre manejo}

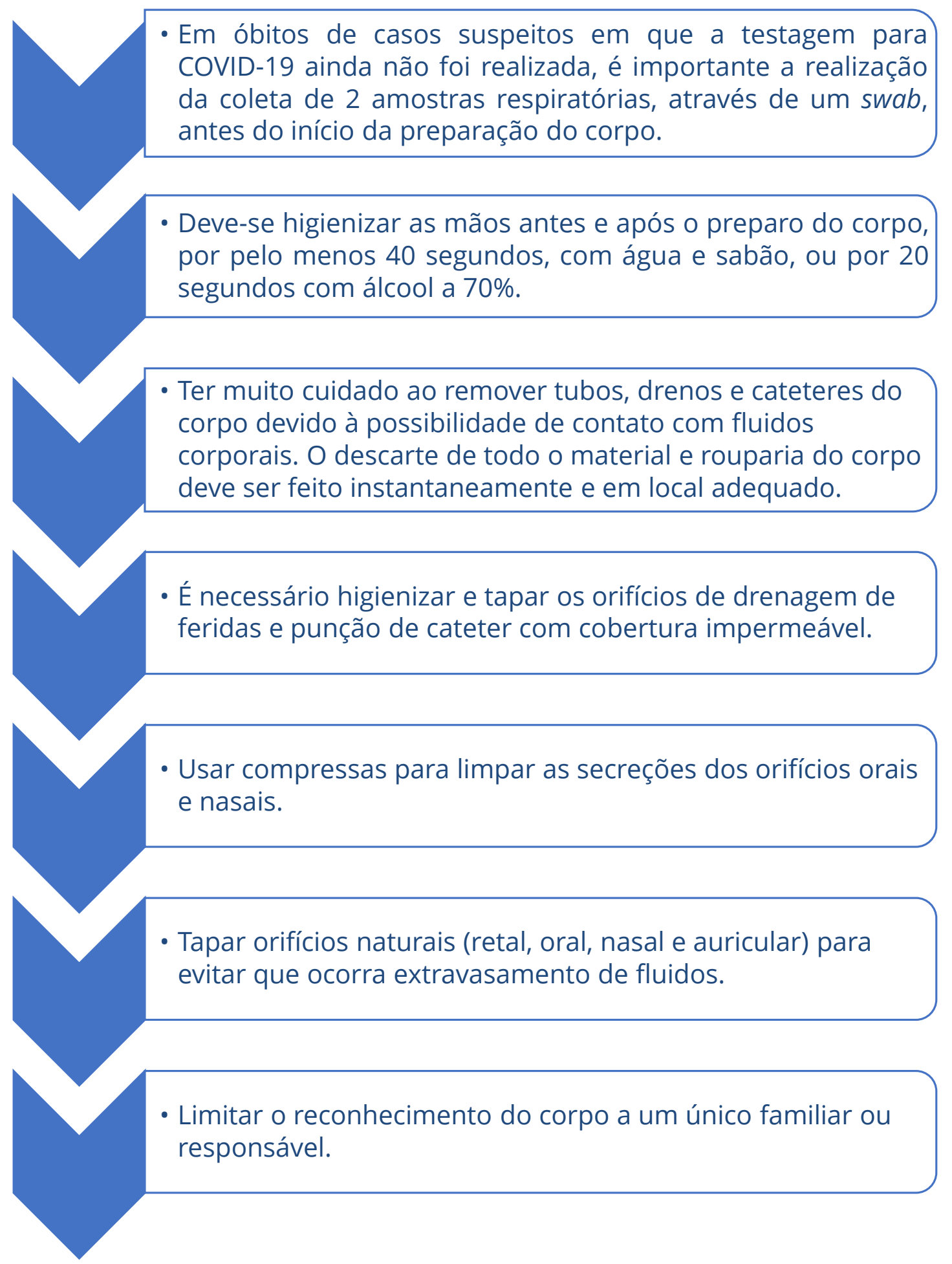

Recomenda-se que não haja contato direto entre o familiar ou responsável e o corpo, mas, caso seja necessário, é importante manter uma distância de dois metros entre eles. Nos casos em que a aproximação 
for necessária para identificação, o familiar ou responsável deve usar máscara, luvas e avental de proteção.

Se a estrutura local permitir, recomenda-se a identificação por meio de fotografias, evitando-se dessa maneira o contato ou exposição. Durante a embalagem do corpo, que deve ocorrer no local do óbito, é conveniente manusear o mínimo possível o corpo para evitar que ocorra a produção ou o extravasamento de gases ou fluidos corporais. É recomendado fazer a identificação do corpo com nome, número do prontuário, número do Cartão Nacional de Saúde (CNS), data de nascimento, nome da mãe e CPF, utilizando, para isso, esparadrapo com letras legíveis, fixado na região torácica.

Ressalta-se que, no prontuário, devem constar todos os sinais externos e marcas de nascença, tatuagens, órteses, próteses que possam ser utilizados como meios de identificação do corpo.

É vedada a realjzação de serviços de somatoconservação, quer seja tanatopraxia, formolização ou embalsamento do corpo.

Quando existir a possibilidade, é recomendado que a embalagem do corpo seja feita em três camadas:

- $1^{\mathrm{a}}$ : Enrolar o corpo com lençóis;

- $2^{\text {a }}$ : Colocar o corpo em saco impermeável próprio (que deve impedir o vazamento de fluidos corpóreos);

- $3^{\mathrm{a}}$ : Colocar o corpo em um segundo saco (externo) e lembrar-se de desinfetar com álcool a 70\%, solução clorada de $0,5 \%$ a $1 \%$ ou outro saneante regularizado pela Anvisa, compatível com o material do saco.

Deve-se colocar etiqueta com identificação do falecido e identificar o saco externo com informações acerca do risco biológico:

\section{COVID-19, agente biológico classe de risco 3.}

Utilizar maca de transporte somente para esse fim. Em caso de reutilização da maca, deve-se desinfetá-la com álcool a 70\%, solução 
clorada de $0,5 \%$ a $1 \%$ ou outro saneante regularizado pela Agência Nacional de Vigilância Sanitária (ANVISA).

Ao chegar ao necrotério, alocar o corpo em local refrigerado e sinalizado como COVID-19, agente biológico classe de risco 3 . O corpo deve ser acomodado em uma urna lacrada em seguida, e realizada uma desinfecção antes da entrega aos familiares ou responsáveis.

É importante lembrar-se de desinfetar a superfície da urna lacrada com solução clorada a $0,5 \%$ antes de levá-la ao funeral ou sepultamento. Porém, deve-se atentar sempre: Após lacrada, a urna não deverá ser reaberta!

Os profissionais responsáveis pelo transporte, guarda e acomodação do corpo no caixão também devem adotar as medidas de proteção aqui expostas até o seu fechamento. O serviço de transporte (ou funerária) deve ser informado de que se trata de uma vítima de COVID-19, agente biológico classe de risco 3.

Após o manuseio do corpo, deve-se retirar e descartar luvas, máscara, gorro e avental (se descartável) em lixo infectante do Grupo A1 - nível de risco 3.

\section{PARA VOCÊ SABER:}

Não é necessário veículo especial para o transporte do corpo, nem é necessária a utilização de EPIs por parte dos motoristas dos veículos que transportarão os caixões com os corpos de vítimas de COVID-19. O mesmo se aplica aos familiares que acompanharão o translado, considerando-se que eles NÃo manuseiam os corpos.

Nos casos em que o motorista necessite fazer o manuseio do corpo, os cuidados acima descritos devem ser tomados. Os falecidos por COVID-19 podem ser enterrados ou cremados. No caso de cremação, dois médicos devem assinar e identificar o CRM na declaração de óbito. Não se deve utilizar ar comprimido, água sob pressão ou qualquer outro método de limpeza de corpos que possa gerar respingos ou aerossóis. 
Considerando a possibilidade de monitoramento, recomenda-se que sejam registrados nomes, datas e atividades de todos os trabalhadores que participaram dos cuidados post mortem, incluindo a limpeza ambiental, bem como de familiares ou outros que tenham tido contato com o falecido.

Não é recomendado que pessoas acima de 60 anos ou que apresentem comorbidades (doenças cardíacas, respiratórias, diabetes), ou ainda as imunossuprimidas realizem atividades relacionadas ao manejo direto do corpo.

Além disso, deve-se dar atenção às pessoas que tiveram contato com o falecido, que devem permanecer em isolamento domiciliar e procurar atendimento médico caso apresentem algum sintoma durante o período subsequente (BRASIL, 2020).

\section{Referências bibliográficas}

BRASIL. Ministério da Saúde. Manejo de corpos no contexto do novo coronavírus COVID-19. 25 Mar 2020. Disponível em: <http:// www.saude.gov.br/images/pdf/2020/marco/25/manejo-corposcoronavirus-versao1-25mar20-rev5.pdf> Acesso em: 19 Jun 2020.

SECRETARIA DE SAÚDE DO MUNICÍPIO DE ARAGUAÍNA. Portaria No 041/GAB/SMS, DE 11 DE MAIO DE 2020. Manejo de corpos na Pandemia do COVID-19. Diário Oficial do Município de Araguaína. 11 Mai 2020. Disponível em: < https://afnoticias.com.br/arquivos/shares/ peddd-6-9.pdf> Acesso em: 19 Jun 2020.

PARANÁ. Secretaria de Saúde do Estado do Paraná. Recomendações gerais para manejo de óbitos suspeitos e confirmados por COVID-19 no Estado do Paraná. Disponível em: < https://www.saude.pr.gov.br/ sites/default/arquivos_restritos/files/documento/2020-06/no_19_ manejo_de_obitos_suspeitos_e_confirmados_por_doenca_por_ covid_19_v2.pdf > Acesso em: 19 Jun 2020. 


\title{
OCORRÊNCIA DOMICILIAR E INSTITUIÇÃO DE MORADIA
}

\author{
Erildo Vicente Muller \\ Jacques Magnos Canossa Mantey \\ Jorge Felipe do Lago Pereira dos Santos
}

Com a intensa urbanização dos municípios brasileiros, a ampliação do acesso aos serviços de saúde - promovida pela capilaridade da Atenção Primária à Saúde e implantação das redes assistenciais - os óbitos no Brasil ocorrem em sua maioria em estabelecimentos de saúde, principalmente em hospitais.

Em situações específicas, tais como: longevos, acamados, e outras, a ocorrência de alguma situação aguda pode contribuir para o não atendimento em tempo da rede de urgência e emergência, e o óbito acontecerá em domicílios ou instituições de longa permanência (ILPI). Ainda, pode ser uma decisão familiar não transportar a pessoa em determinadas situações de saúde e lhe permitir que faleça na residência sob o aconchego dos familiares.

Deste modo, os óbitos em locais de residência são menos frequentes que os hospitalares, mas, passíveis de ocorrência. Caso venham a ocorrer óbitos no ambiente domiciliar ou em ILPI, em suspeitos ou confirmados de COVID, os cuidados a seguir devem ser tomados, principalmente pelas pessoas que moram na mesma residência, as quais devem ser alertadas na primeira oportunidade.

As pessoas que reportarem o óbito devem ser orientadas a não manipular o corpo e evitar o contato direto. No local de residência, os ambientes e objetos em que houve contato do falecido devem ser desinfetados com solução clorada. Essa solução consiste em água sanitária misturada com água, na concentração de $0,1 \%$ a $0,5 \%$, sendo que cada concentração tem finalidade diferente, conforme descrito a seguir: 
- Para descontaminação de superfícies mais delicadas, como roupas, calçados, interior do carro, chaves, celulares e similares, é recomendada a concentração 0,1\% de água sanitária. Um copo de $200 \mathrm{ml}$ de água sanitária (concentração de 2\% a 2,5\%) em 5 litros de água.

- Para áreas mais resistentes, como o chão, maçanetas, paredes e outras, pode ser usada a solução de $0,5 \%$, ou seja, 1 litro de água sanitária para 4 litros de água.

Figura 1 - Diluição de solução clorada a 0,1\% e 0,5\% para desinfecção de superfícies.
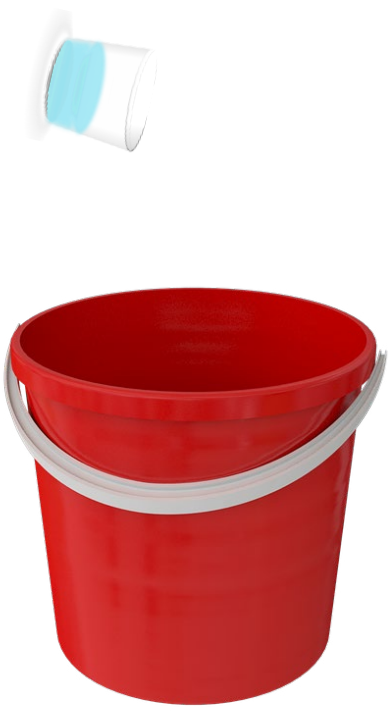
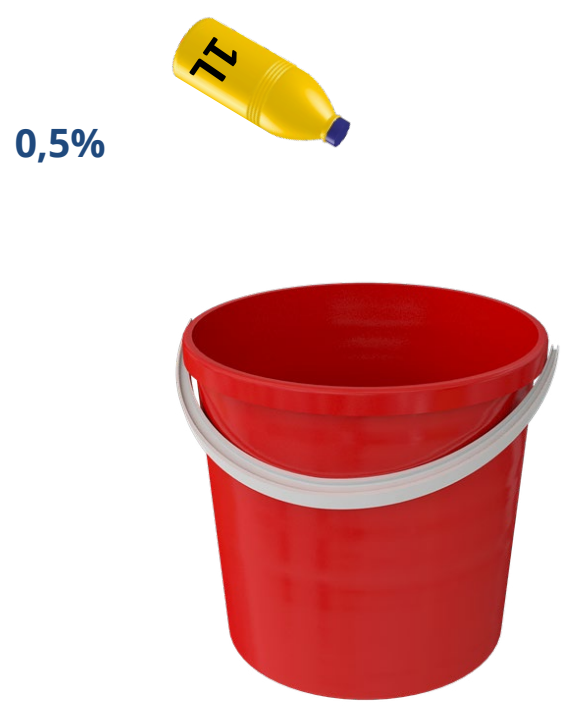

Fonte: Os autores.

O médico que for constatar o óbito deverá utilizar os EPIs recomendados, como óculos de proteção, gorro, máscara cirúrgica, avental e luvas descartáveis. Em procedimento que gere aerossol, como extubação ou coleta de amostra respiratória, é indicado o uso de máscara N95 ou equivalente.

Imediatamente após a informação do óbito, o médico atestante deve notificar a equipe de vigilância em saúde para verificar a necessidade de coleta de amostras para exame. 


\section{Morte sem sinais evidentes de causa externa}

Os óbitos residenciais podem acontecer em pessoas com ou sem sinais de morte por causas externas (violências, acidentes, afogamentos, intoxicações e outros). Como neste Manual o manejo de corpos trata especificamente de pessoas suspeitas ou confirmadas de terem COVID, parte-se da premissa que o manejo se dará em corpos que tenham falecido sem envolvimento de causas externas.

Assim, em caso de morte por COVID, sem sinais evidentes de causa externa definidos, o médico que acompanhava o paciente (na UBS, clínica, hospital, consultório, casas de repouso etc.) deve constatar o óbito e, após identificação do corpo, preencher a declaração de óbito. $\mathrm{Na}$ ausência ou indisponibilidade do médico assistente, ele ou o serviço ao qual pertence deve designar um médico substituto para a constatação e preenchimento da declaração de óbito. Na impossibilidade das opções anteriores, o serviço público de saúde mais próximo, uma Unidade Básica de Saúde (UBS) quando em horário de funcionamento, ou o Serviço de Atendimento Móvel de Urgência (SAMU), nos demais horários, deve ser acionado para a constatação e preenchimento da declaração de óbito. Quando o atendimento ocorre por serviços médicos volantes (SAMU ou empresas similares), o médico intervencionista desse serviço constata o óbito, devendo preencher a declaração de óbito (DO).

Caso a família opte pela cremação, cabe ao médico que está preenchendo a DO solicitar a segunda assinatura e carimbo médico na declaração de óbito, podendo se utilizar do serviço público mais próximo para tal, podendo ser UBS ou Unidade de Pronto Atendimento (UPA).

- Nos casos de dificuldade de identificação do corpo, o serviço móvel de papiloscopia do Instituto de Identificação do Paraná deve ser acionado para ir até o local e realizar a identificação, dando sequência aos passos anteriores.

- Se não for possível a identificação do corpo (por exemplo, em avançado estado de putrefação ou pessoas sem registro no Estado), a Polícia Civil deve ser acionada pelo 197 para as devidas providências. 


\section{Morte com sinais evidentes de causa externa (acidentes e violências)}

Se houver algum indício de que o óbito envolva sinais de causas externas, a família ou pessoa que identificou a situação ${ }^{1}$ acionará um agente de segurança pública de sua localidade (pelos telefones 190-Polícia Militar, 153-Guarda Municipal ou 197-Polícia Civil) para abertura do boletim de ocorrência, guarda do corpo e preservação da cena.

\section{Acionamento do Instituto Médico Legal (IML)}

O IML faz a busca do corpo em veículo próprio e exclusivo para esse fim, realiza os procedimentos necessários e emite a declaração de óbito.

\section{Referências bibliográficas}

BRASIL. Ministério da Saúde. Manejo de corpos no contexto do novo coronavírus COVID-19. 25 Mar 2020. Disponível em: <http:// www.saude.gov.br/images/pdf/2020/marco/25/manejo-corposcoronavirus-versao1-25mar20-rev5.pdf> Acesso em: 19 Jun 2020.

SECRETARIA DE SAÚDE DO MUNICÍPIO DE ARAGUAÍNA. Portaria No 041/GAB/SMS, DE 11 DE MAIO DE 2020. Manejo de corpos na Pandemia do COVID-19. Diário Oficial do Município de Araguaína. 11 Mai 2020. Disponível em: < https://afnoticias.com.br/arquivos/shares/ peddd-6-9.pdf> Acesso em: 19 Jun 2020.

PARANÁ. Secretaria de Saúde do Estado do Paraná. Recomendações gerais para manejo de óbitos suspeitos e confirmados por COVID-19 no Estado do Paraná. Disponível em: < https://www.saude.pr.gov.br/ sites/default/arquivos_restritos/files/documento/2020-06/no_19_ manejo_de_obitos_suspeitos_e_confirmados_por_doenca_por_ covid_19_v2.pdf > Acesso em: 19 Jun 2020.

\footnotetext{
${ }^{1}$ Nas causas de morte confirmadas ou suspeitas por causa externa, a DO deverá obrigatoriamente ser preenchida pelo Instituto Médico Legal (IML), qualquer que tenha sido o tempo decorrido entre o evento violento e a morte.

As equipes assistenciais, da UBS, Serviço Integrado de Atendimento ao Trauma em Emergência (SIATE), ou do SAMU), que se depararem com a situação, devem proceder da mesma maneira, aguardando no local até a chegada do agente de segurança.
} 


\section{QUANDO O ÓBITO OCORRER EM ESPAÇO PÚBLICO}

\section{Pollyanna Kássia de Oliveira Borges \\ Ricardo Zanetti Gomes \\ Lislei Terezinha Preuss}

Os óbitos em espaço público não são tão comuns quanto os que ocorrem em serviços de saúde ou domicílios, no entanto podem acontecer. E, quando ocorrerem, deve-se ter cautela e adotar medidas de precaução, todas aquelas que se tomariam em outros locais, acrescidas das específicas para a situação.

Espera-se que óbitos em espaço público por COVID-19 sejam raríssimos, primeiro porque o paciente grave deve receber assistência médica, e porque pode haver dificuldades para certificar que a causa da morte tenha sido a COVID-19.

Em tempo de pandemia, quando o óbito se der em espaços públicos, o primeiro passo é evitar tocar e manipular o corpo, inclusive indica-se afastar as pessoas que estiverem próximas ao corpo (SÃO PAULO, 2020). Recomenda-se informar as autoridades policiais e serviços de urgência: SAMU, SIATE ou outros. Estes devem tomar as devidas ações para confirmação do óbito e verificação da causa.

As autoridades avaliarão a possibilidade de o óbito ter sido causado por causas externas. Caso seja confirmada tal possibilidade, o corpo deverá ser encaminhado ao IML.

Entretanto, se a morte for natural, o médico do SAMU, SIATE, resgate de concessionárias de pedágio ou outros serviços similares devem constatar a morte. Segundo o Ministério da Saúde (BRASIL, 2020), o manejo do corpo deve seguir as mesmas orientações dos óbitos que acontecem no domicílio (BAHIA, 2020) e já descritos no capítulo 2. 
Havendo material disponível, pessoas treinadas e indícios na Autopsia Verbal de suspeita de Síndrome Gripal, Síndrome Respiratória Aguda Grave (SRAG) ou COVID-19, é possível que o médico ou enfermeiro da equipe que atender ao evento possa realizar a coleta naso-orofaríngea no corpo, de acordo com os procedimentos operacionais padrões descritos neste Manual. Porém, em cada caso deve ser considerada a necessidade específica da situação.

Se a coleta for realizada, o material coletado deve ser encaminhado ao serviço de vigilância epidemiológica municipal, junto com a ficha de notificação compulsória para casos suspeitos ou confirmados de COVID-19 (Figura 3).

Figura 2 - Ficha de notificação COVID-19 (primeira página) do Estado do Paraná.

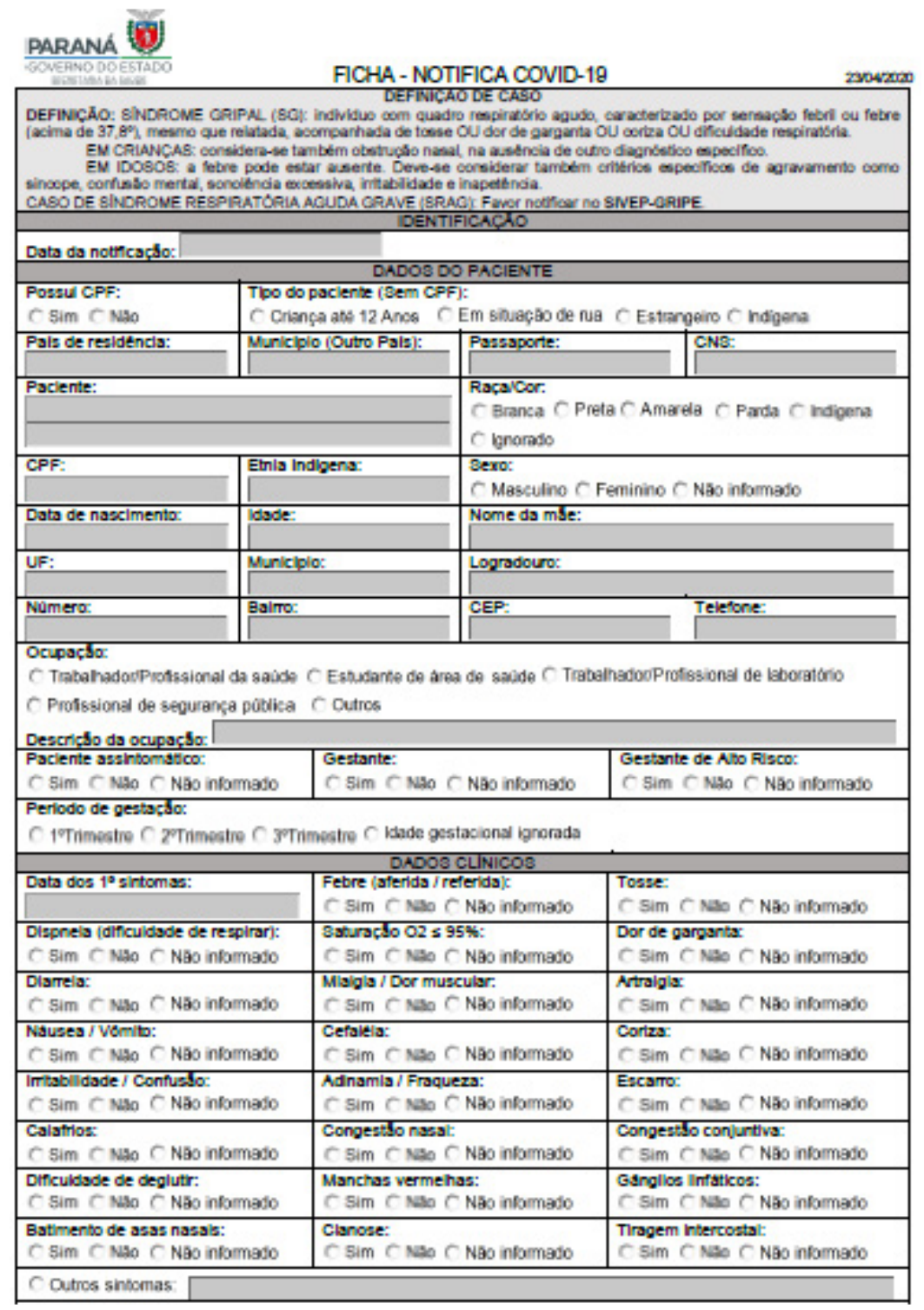

Fonte: PARANÁ, 2020. 
Embalagem, transporte e higiene para óbitos em espaços públicos são os mesmos prescritos para óbitos hospitalares (CEARÁ, 2020).

\section{Referências bibliográficas}

MINISTÉRIO DA SAÚDE. Manejo de corpos no contexto do novo coronavírus COVID-19. 25 Mar 2020. Disponível em: <http://www. saude.gov.br/images/pdf/2020/marco/25/manejo-corposcoronavirus-versao1-25mar20-rev5.pdf> Acesso em: 24 Jun 2020.

SÃO PAULO. Secretaria de Estado da Saúde. Coordenadoria de controle de doenças. Orientações para casos de óbitos durante a Pandemia de COVID-19 [Internet]. Disponível em: <http://www.accamargo.org.br/ sites/default/files/2020-04/GERAL_-_Orienta\%C3\%A7\%C3\%B5es_ para_casos_de_\%C3\%B3bitos_durante_pandemia_ COVID_2020_04_15_V1.pdf> Acesso em: 24 Jun 2020.

BAHIA. Secretaria da Saúde do Estado da Bahia. Nota Técnica N. 9 DE 27 de MARÇO DE 2020. Orientações para gestores, para manejo de óbitos em domicílio, instituições de moradia, unidades hospitalares, espaços públicos, funerárias, e coletas após a morte, no período da pandemia de COVID-19. Disponível em:<http://www.saude.ba.gov.br/wp-content/ uploads/2020/03/NT_n-9_27-03_Orientac\%CC\%A7o\%CC\%83esManejo-de-cada\%CC\%81veres-em-domici\%CC\%81lioespac\%CC\%A7os-pu\%CC\%81blicos-servic\%CC\%A7os-desau\%CC\%81de-Funera\%CC\%81rias.pdf> Acesso em: 24 Jun 2020.

CEARÁ. Secretaria da Saúde do Estado do Ceará. Nota Técnica. Procedimentos relacionados ao óbito por coronavírus (COVID-19). Disponível em: https://www.saude.ce.gov.br/wp-content/uploads / sites/9/2020/02/Nota-Manejo-Obitos-COVID-19.pdf. Acesso em: 24 Jun 2020 .

PARANÁ. Secretaria de Saúde do Estado do Paraná. Ficha Notifica COVID-19. Disponível em: http://www.sjp.pr.gov.br/wp-content/ uploads/2020/05/ficha_fisica_notificacao_covid_19.pdf. Acesso em: 16 dez 2020. 


\section{RECOMENDAÇÕES PARA COLETA DE TECIDOS E MANIPULAÇÃO DE AMOSTRAS}

Pollyanna Kássia de Oliveira Borges

Fabiana Postiglione Mansani

Carlos Eduardo Coradassi

Lorena Slusarz Nogueira

Sempre que possível, as amostras biológicas devem ser coletadas enquanto o paciente estiver vivo, o que possibilita a intervenção sobre o caso clínico. Porém, caso não seja possível a coleta em vida, a equipe assistente, ou o serviço de epidemiologia e controle de infecções, deve coletar amostra da cavidade naso-orofaríngea com swab e inserir no meio de transporte viral (Figura 3).

Figura 3 - Meio de transporte viral para inserção de material biológico para análise laboratorial de suspeita COVID-19

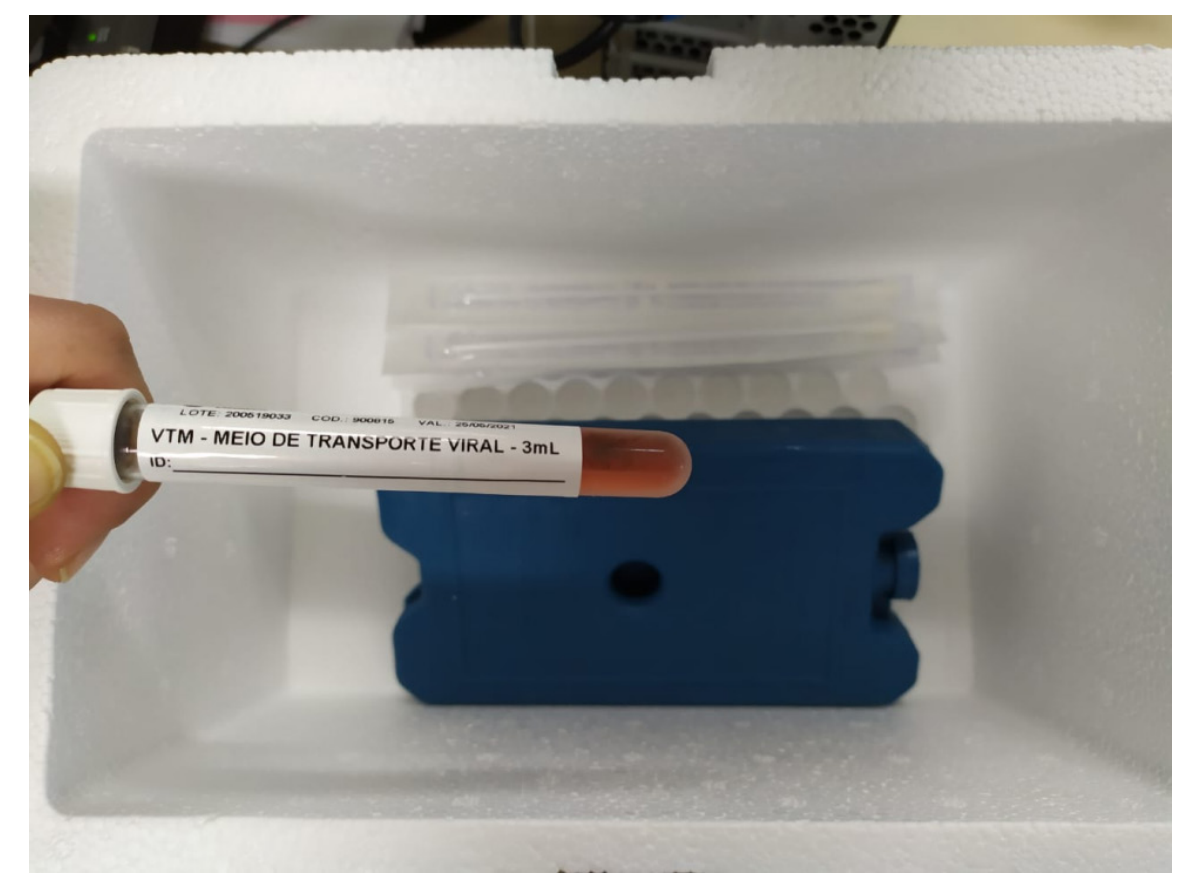


Naqueles casos em que houver um resultado negativo do exame RT-PCR (do inglês reverse-transcriptase polymerase chain reaction, reação em cadeia da polimerase-transcriptase reversa), e após ampla discussão, considerado o contexto de risco e benefício, optar-se pela coleta de tecidos, o Ministério da Saúde sugere que se proceda a "necropsia minimamente invasiva", que consiste basicamente em utilizar métodos de imagem e punção percutânea para coleta de fragmentos de tecido e envio para análise laboratorial (BRASIL, 2020).

As amostras devem ser encaminhadas para processamento e análise laboratorial em caixa refrigerada com gelo reutilizável rígido (Figura 5), acopladas em recipiente que permita a estabilidade dos frascos.

No laboratório, se houver cabines de segurança biológica, elas devem ser usadas na manipulação e investigação de amostras pequenas. A sala de análise deve ser apropriada e o profissional que manipular as amostras, desde a coleta, armazenagem e análise devem estar paramentado com equipamentos de proteção individual (listados na Tabela 1). A higiene das mãos deve ser efetivada antes e após o preparo, coleta e análise das amostras (UFRGS, 2020).

Toda unidade de saúde deve estabelecer o fluxo de coleta e processamento das amostras (BRASIL, 2020).

Figura 4 - Caixa refrigerada com gelo reutilizável e recipiente para transporte de material biológico

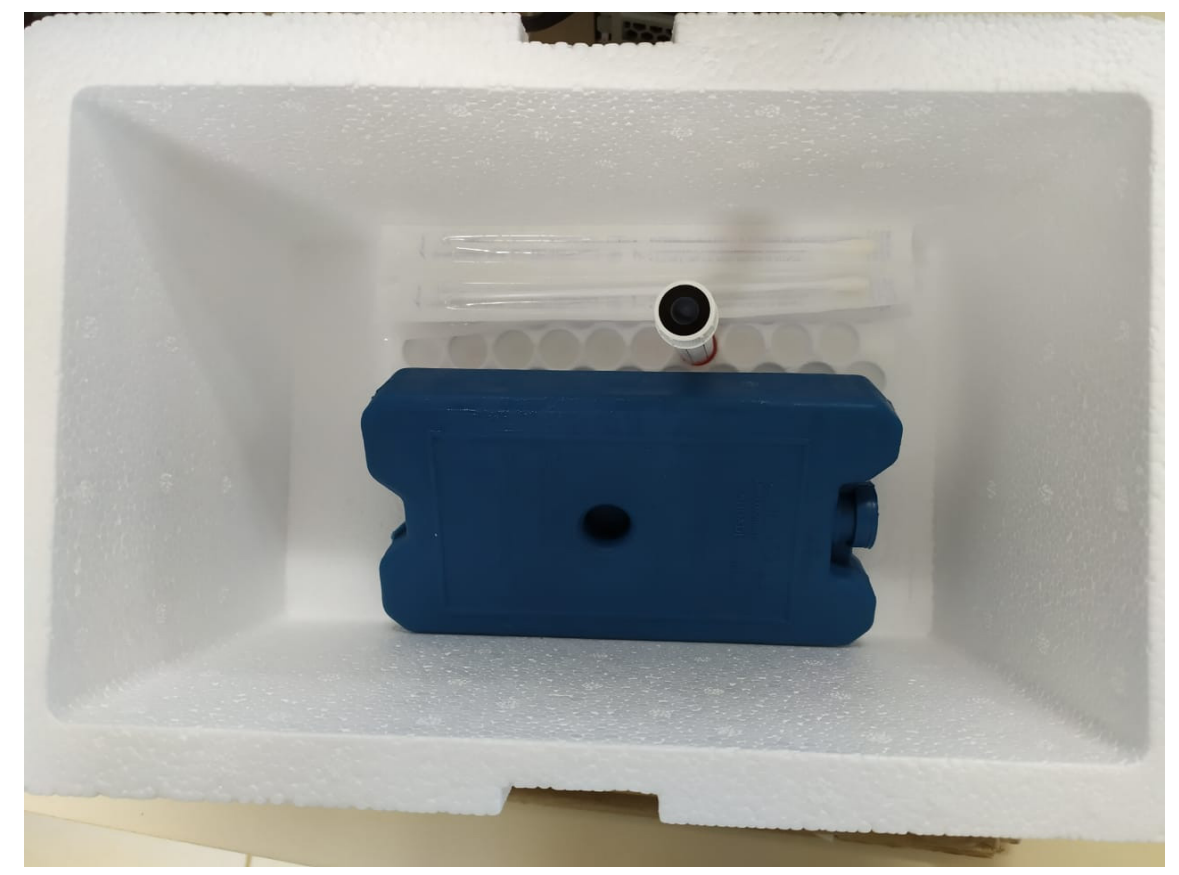


Tabela 1 - Equipamentos de Proteção Individual necessários ao uso daqueles que manipulam amostras de casos suspeitos ou confirmados COVID-19.

\section{PROTETOR FACIAL}

\section{MACACÃO SOB AVENTAL OU AVENTAL IMPERMEÁVEL DE MANGA COMPRIDA}

MÁSCARA N95

ou superior

\section{LUVAS}

Utilizar luvas de autopsia ou dois pares de luvas de látex

\section{BOTAS IMPERMEÁVEIS}

Fonte: UFRGS, 2020. Adaptado.

\section{Referências bibliográficas}

BRASIL. MINISTÉRIO DA SAÚDE. Manejo de corpos no contexto do novo coronavírus COVID-19. 25 Mar 2020. Disponível em: <http:// www.saude.gov.br/images/pdf/2020/marco/25/manejo-corposcoronavirus-versao1-25mar20-rev5.pdf> Acesso em: 24 Jun 2020.

UNIVERSIDADE FEDERAL DO RIO GRANDE DO SUL (UFRGS). Como fazer a investigação de COVID-19 após o óbito em casos suspeitos?. [Internet] Disponível em: < https://www.ufrgs.br/telessauders/posts_ coronavirus/como-fazer-a-investigacao-de-covid-19-apos-o-obitoem-casos-suspeitos/> Acesso em: 24 Jun 2020. 


\section{EMISSÃO DE \\ DECLARAÇÃO DE ÓBITO}

Felício de Freitas Netto

Maria Cleonice Alves

Mauriceia de Souza Ribeiro

Caroline Soczek da Silva

A Declaração de Óbito (DO) é o documento padrão, no território nacional, para registrar, atestar ou declarar um óbito. É utilizado, também, como documento para base do cálculo das estatísticas vitais e epidemiológicas do Brasil, considerado como documento hábil para os fins do art. 77 da Lei $n^{\circ}$ 6.015/1973 (BRASIL, 1973) para a lavratura da Certidão de Óbito pelo Cartório de Registro Civil (art. 10 da Portaria ${ }^{\circ}$ $116 \mathrm{MS} / \mathrm{SVS}$ de 11/02/2009) (BRASIL, 2009). Dentre as finalidades de uma DO, constam a documentação do óbito para procedimentos legais e, ao falar-se em Saúde Pública, adicionam-se os objetivos epidemiológicos para análise, planejamento e formação de políticas públicas.

O instrumento padronizado é impresso com sequência numérica única. O controle da numeração, bem como a emissão e distribuição dos formulários para as Secretarias Estaduais de Saúde é de competência exclusiva do Ministério da Saúde, pela sua Secretaria de Vigilância em Saúde (Art. 12 da Portaria nº 116 MS/SVS de 11/02/2009) (BRASIL, 2009)

A padronização das causas de morte é fundamental, pois é acordada entre todos os países-membros da Organização Mundial da Saúde (OMS) e obedecem a regras de codificação estabelecidas por esse órgão. Para estatísticas de mortalidade, pressupõe-se que para cada óbito há uma única causa. Quando duas ou mais causas de morte estiverem relatadas na DO, aplica-se o regramento internacional, a fim selecionar a causa básica do óbito estabelecido pela Classificação Estatística Internacional de Doenças e Problemas Relacionados à Saúde (CID-10) (BRASIL, 2020b). 


\section{O médico e a declaração de óbito}

O médico tem responsabilidade ética e jurídica pelo preenchimento e assinatura da DO, assim como pelas informações registradas em todos os campos desse documento. As informações nele presentes são utilizadas na produção das estatísticas de mortalidade e concorrem para a identificação do processo mórbido, conduzindo ao conhecimento do perfil saúde-doença.

\section{6 Ė vedado ao médico:}

Art. 115. Deixar de atestar óbito de paciente ao qual vinha prestando assistência, exceto quando houver indícios de morte violenta.

\section{gy}

(Conselho Federal de Medicina, 2018)

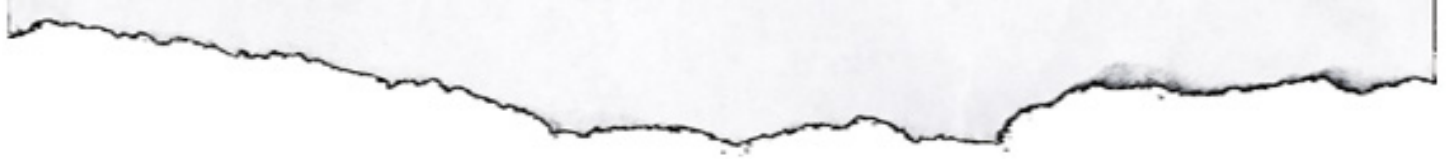

Fonte: Conselho Federal de Medicina, 2018.

A emissão da DO é um ato médico; portanto, ocorrido um óbito, o médico tem a obrigação legal de constatá-la e atestá-la, utilizando o formulário-padrão para tal finalidade, como promulga a Resolução do Conselho Federal de Medicina $n^{\circ} 1779$. É importante que o responsável pelo preenchimento o faça com respeito aos preceitos legais e epidemiológicos vigentes. Os direitos, deveres e obrigações do médico são definidos pelo Código de Ética Médica. (Conselho Federal de Medicina, 2018)

\section{Art. $1^{\circ}$}

O preenchimento dos dados constantes na Declaração de Obito é da responsabilidade do médico que atestou a morte. g

(Conselho Federal de Medicina, 2005)

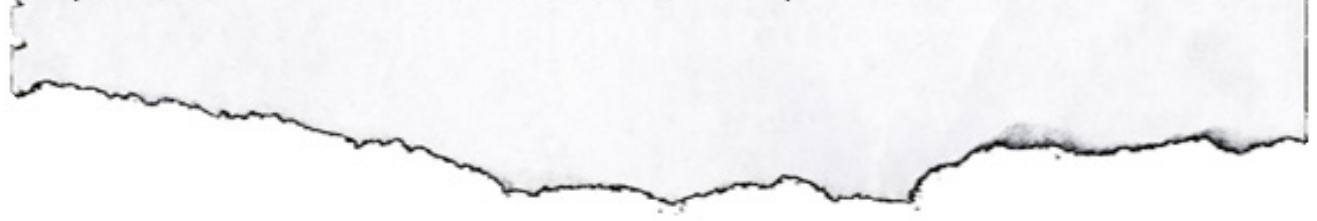

Fonte: Conselho Federal de Medicina, 2018. 
O médico atestante deve se abster de utilizar diagnósticos vagos como "parada cardíaca", "parada cardiorrespiratória" e "falência de múltiplos órgãos", pois são modos e não causas de morte, não devendo ser computados como causa básica do óbito em uma declaração de óbito.

No Brasil, há profissionais capacitados em codificação de Causa Básica do Óbito - CID-10, que realizam a seleção e codificação da causa básica da DO com base na descrição do médico. Esses profissionais se inserem nos serviços de vigilância epidemiológica dos municípios.

\section{Definições das causas de morte: definição universal}

Conforme orientação para o preenchimento da Declaração de (BRASIL, 2009), tem-se definido que a causa da morte tange a doenças, estados mórbidos ou lesões que produziram a morte ou contribuíram para ela, e as circunstâncias do acidente ou da violência que produziu estas lesões.

\section{Causa básica de morte}

O óbito, geralmente, não é consequência de um evento único, mas de uma cadeia de eventos concatenados.

\section{Causa Básica}

É definida como a doença ou circunstância que iniciou a cadeia de eventos mórbidos que levou diretamente à morte (BRASIL, 2009).

Têm-se, ainda, outros conceitos como morte natural, a qual referencia uma doença ou lesão que iniciou a cadeia de acontecimentos patológicos que conduziram diretamente à morte; e a causa externa (circunstâncias do acidente ou violência que produziram a lesão fatal).

\section{Causas intermediárias}

As causas intermediárias do óbito remetem aos estados mórbidos que produziram a causa terminal. (BRASIL, 2009). 


\section{Causa terminal}

A causa terminal do óbito diz respeito à doença ou estado mórbido que causou diretamente a morte. (BRASIL, 2009).

\section{Causas associadas (outras condições)}

Outras condições significativas que contribuíram para a morte e que não entraram na sequência de eventos que culminaram com o óbito. Elas são registradas na Parte II do Bloco V da declaração de óbito, conforme Figura 7, a seguir

Figura 5 - Exemplo de preenchimento das causas de óbito por COVID-19, com associação de comorbidades crônicas.

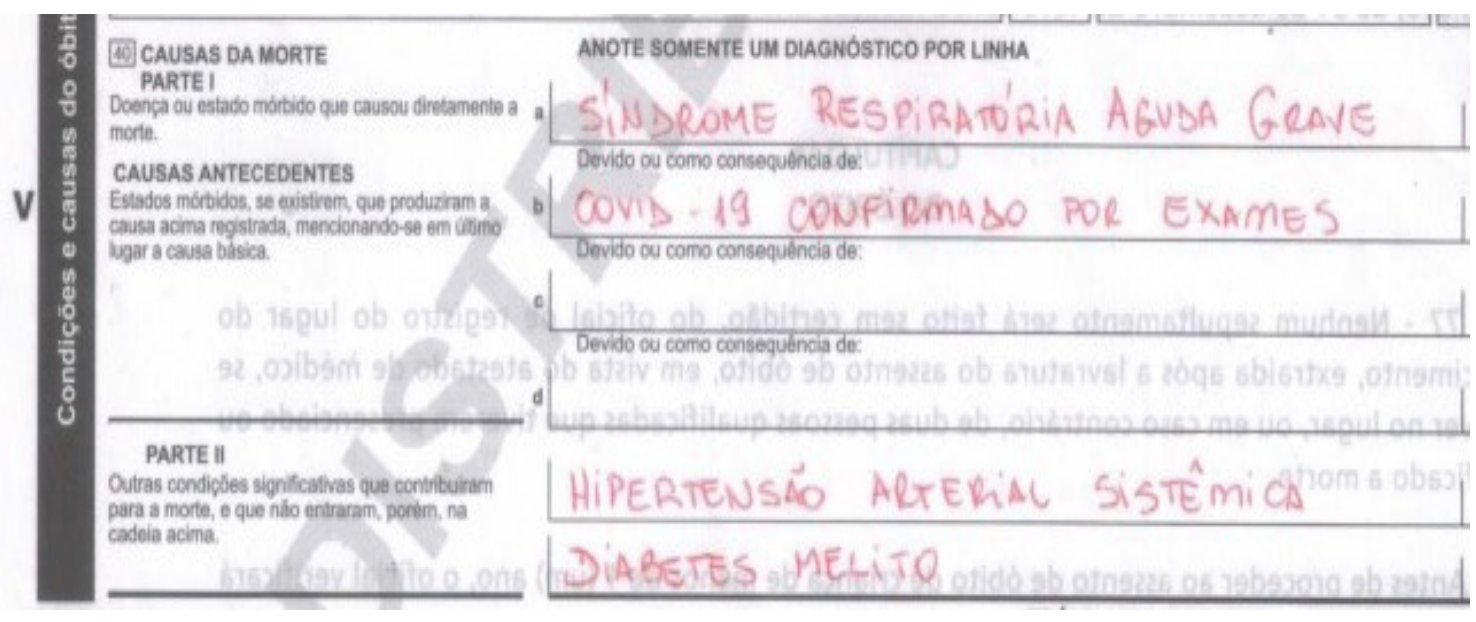

Fonte: $3^{\text {a }}$ Regional de Saúde de Ponta Grossa, Paraná, Brasil. 2020.

Figura 6 - Exemplo de preenchimento das causas de óbito em suspeitos COVID-19.

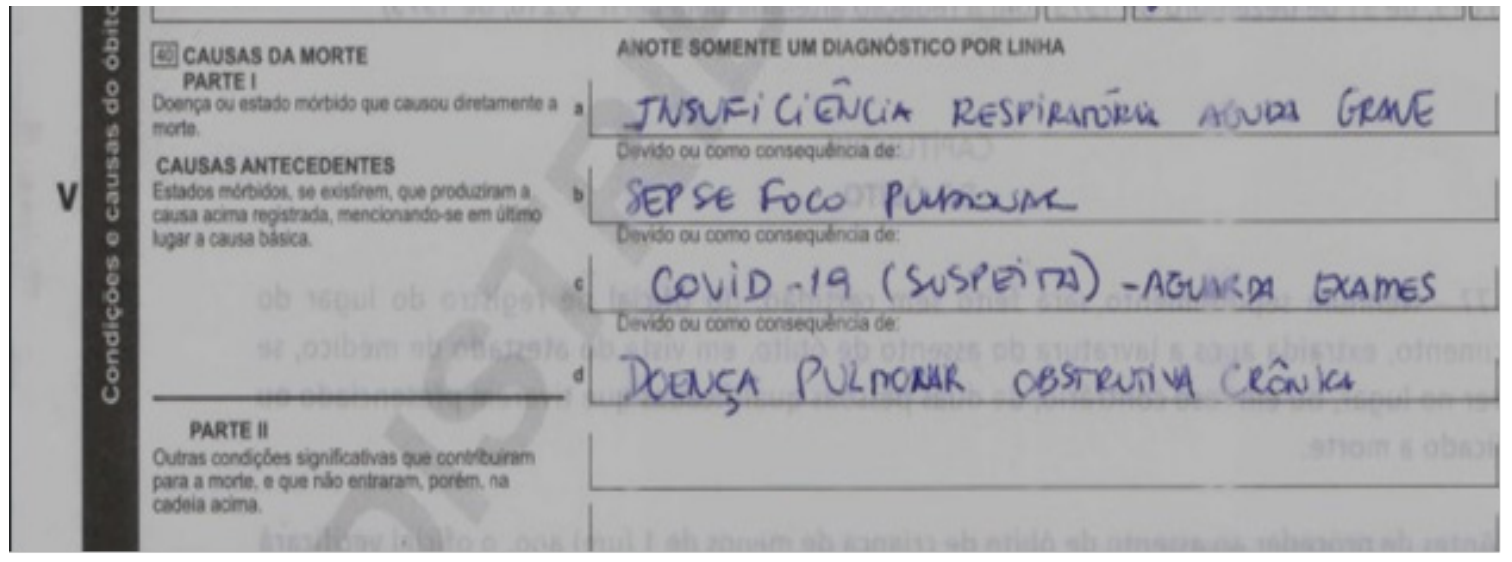

Fonte: $3^{\text {a }}$ Regional de Saúde de Ponta Grossa, Paraná, Brasil. 2020. 


\section{ATENÇÃO}

Regras de preenchimento das causas de morte:

- Registrar apenas uma doença, alteração ou lesão em cada linha.

- Para cada causa registrada, indicar, no campo à direita, o tempo aproximado entre o início da doença e a morte (em horas, dias, meses ou anos). Se este tempo for desconhecido, preencher "desconhecido".

- Não colocar siglas: IAM, FA, IRC, BAV, entre outras.

1. CID - Não preencher, espaço destinado aos codificadores dos serviços de estatística dos municípios.

2. O médico é responsável não só por atestar as causas de óbito, mas pelo preenchimento e assinatura de toda a DO.

Conforme orientações do Ministério da Saúde acerca da Declaração de Óbito no contexto da COVID-19 (BRASIL, 2020), ao preencher a DO, utilizar os seguintes códigos:

- B34.2 (Infecção por corona vírus de localização não específica)

- U07.1 (COVID-19, vírus identificado);

- U07.2 (COVID-19, vírus não identificado, clínico-epidemiológico).

Ainda de acordo com o mesmo protocolo do Ministério da Saúde, a COVID-19 deve estar alocada na parte I do atestado, compondo a sequência lógica de eventos registrada pelo médico. Além disso, pessoas com COVID-19 podem morrer de outras doenças ou acidentes, o que não será registrado como morte devido à COVID-19. Caso o certificante considere que a COVID-19 tenha agravado ou contribuído para a morte, poderá relatar esse fato na parte II do atestado. Ressalta-se que, diante de um resultado negativo para o swab naso-orofaríngeo, em virtude do contexto epidemiológico do país, deve-se proceder a discussão individualizada do caso. Nessa discussão, considerar a observação clínica e os resultados de exames de imagem, como a tomografia computadorizada, para possível confirmação de morte por COVID-19. 


\section{Orientações para preenchimento correto da declaração de Óbito no contexto da Covid-19:}

Caso confirmado antes do
óbito com SRAG
• Preencher na linha A:
"Síndrome Respiratória Aguda
Grave".
- Na linha B: "COVID-19
confirmado por exame". •Parte
II: comorbidades ou fatores
contribuintes.

Caso suspeito com SRAG

- Preencher na linha A:

"Síndrome Respiratória Aguda Grave".

- Na linha B: "suspeito COVID-

19 - aguarda exames".

- Parte II: comorbidades ou fatores contribuintes.

\section{Caso confirmado antes do óbito sem SRAG \\ - Preencher na linha A: síndrome clínica que o paciente apresentou. Ex: sepse; insuficiência cardíaca descompensada. \\ -Na linha B: "COVID-19 confirmado por exames". \\ - Parte II: comorbidades ou fatores contribuintes.}

\section{Caso suspeito sem SRAG}

- Preencher na linha A causa imediata do óbito Ex: sepse.

- Na linha B: "suspeito COVID-19

- aguarda exames".

- Parte II comorbidades ou fatores contribuintes.

Em caso de óbito suspeito em que não seja possível a coleta de exames, colocar "suspeito de COVID-19. Não foi possível coletar exames".

\section{Referências bibliográficas}

BRASIL. Lei $n^{\circ} 6.015$ de 31 de dezembro de 1973. Dispõe sobre os registros públicos e dá outras providências. Disponível em <http:// www.planalto.gov.br/ccivil_03/leis /L6015compilada.htm>. Acesso em 20 set. 2020. 
BRASIL. Ministério da Saúde. Secretaria de Vigilância em Saúde. Portaria $\mathrm{n}^{\circ} 116$, de 11 de fevereiro de 2009. Regulamenta a coleta de dados, fluxo e periodicidade de envio das informações sobre óbitos e nascidos vivos para os Sistemas de Informações em Saúde sob gestão da Secretaria de Vigilância em Saúde. Disponível em < http://bvsms.saude.gov.br/bvs/ saudelegis/svs/2009/prt0116_11_02_2009.html> Acesso em 16 dez 2020.

BRASIL. Departamento de Informática do Sistema Único de Saúde. Classificação Estatística Internacional de Doenças e Problemas Relacionados à Saúde (CID-10). Disponível em < http://datasus1.saude. gov.br/sistemas-e-aplicativos/cadastros-nacionais/cid-10>. Acesso em 16 dez 2020.

CONSELHO FEDERAL DE MEDICINA. Resolução CFM n 1.779/2005. Regulamenta a responsabilidade médica no fornecimento da Declaração de Óbito. Revoga a Resolução CFM n. 1601/2000. Disponível em < https://sistemas.cfm.org.br/normas/visualizar/resolucoes / BR/2005/1779>. Acesso em 16 dez 2020.

BRASIL. Ministério da Saúde. Conselho Federal de Medicina. Centro Brasileiro de Classificação de Doenças. A declaração de óbito:

documento necessário e importante. 3. ed. Brasília: Ministério da Saúde, 2009. 


\section{PROCEDIMENTO OPERACIONAL PADRÃO PARA IDENTIFICAÇÃO, MANEJO E TRANSPORTE PÓS-ÓBITOS POR COVID-19}

Carolina Ribeiro Duarte

Maria Dagmar da Rocha

Gabriela Benassi

Lorena Slusarz Nogueira

\section{Objetivo}

Orientar quanto aos cuidados em relação à identificação, manejo e transporte pós-óbito do corpo de pacientes com suspeita ou confirmação de COVID-19 e medidas de precaução para evitar a contaminação dos profissionais envolvidos no procedimento e transporte do corpo.

Este capítulo tem por intuito auxiliar as equipes de saúde de medicina legal e funerárias em relação ao manejo dos corpos dos pacientes acometidos pela COVID-19 nos ambientes hospitalares, pois, ao se tratar de uma doença infecciosa, ela pode ser transmitida durante o manejo desses corpos.

Tal prática é agravada em caso de ausência ou uso inadequado dos equipamentos de proteção individual (EPIs). Desse modo, é de suma importância que os profissionais tomem cuidados, visto que o vírus SARS-CoV-2 é transmitido por contato, por isso é fundamental que todos estejam protegidos da exposição a sangue e fluidos corporais, objetos ou outras superfícies contaminadas 


\section{Materiais}

Os materiais necessários à proteção individual dos profissionais que trabalham com os procedimentos com os corpos, após a morte, são os seguintes.

- Equipamento de proteção individual - avental impermeável de manga comprida, luvas de procedimento, óculos protetores ou protetor facial, gorro, máscara cirúrgica em procedimentos que não gerem aerossóis e máscara N95 ou PFF2 em procedimentos que gerem aerossóis (extubação).

- Álcool a 70\%;

- Algodão e gazes;

- Atadura;

- Esparadrapo ou fita adesiva;

- Lençol;

- Sacos de óbito (duas unidades);

- Identificação do corpo;

- Pinça longa (Cheron);

- Filmes transparentes;

- Recipiente para o descarte de materiais perfurocortantes;

- Tesoura ou bisturi, se necessário;

- Bacia com água, se necessário;

- Papel-toalha, se necessário;

- Sabonete líquido, se necessário;

- Compressa, se necessário;

- Bandeja;

- Biombo;

- Hamper;

- Maca sem colchão;

- Sistema de aspiração (cateter de aspiração de 10 a 14 em silicone, frascos aspiração a vácuo), se necessário. 


\section{Descrição geral do procedimento}

- Todas as pessoas envolvidas devem usar Equipamentos de Proteção Individual (EPI) de uso exclusivo.

- O médico deverá realizar a constatação do óbito e registrar.

- Devem ser respeitadas a dignidade dos mortos, sua cultura, religião, tradições e suas famílias.

- A equipe de saúde deve limitar-se ao número suficiente para realizar as atividades com segurança.

- A higiene das mãos deve ser realizada.

- Verificar se já havia sido realizada coleta de secreção naso-orofaríngea antes do óbito. Caso não tenha sido, ou a amostra esteja em andamento, a coleta deverá ser realizada para estabelecer a causa do óbito, ou se realizar um teste rápido validado pelo Ministério da Saúde.

- Fechar os olhos do paciente, pressionando as pálpebras. Caso não seja possível, fixá-las com tiras de fitas adesivas.

- Realizar tamponamento dos orifícios de drenagem (narinas, ouvidos e regiões orofaríngea, vaginal e anal) com algodão seco, por meio de uma pinça longa, de tal maneira que não apareça o algodão e finalizar com cobertura impermeável para evitar riscos de extravasamento de fluidos.

- Na presença de sujidades aparentes (sangue, secreção), realizar uma rápida limpeza corporal, lavando com água e sabão.

- Sustentar a mandíbula com atadura, amarrando-a no alto da cabeça.

- Unir as mãos sobre a região epigástrica e fixando-as com atadura e respeitando a posição anatômica.

- Aproximar os pés e fixá-los com atadura respeitando a posição anatômica. 
- Sempre que possível, a embalagem do corpo deve seguir três camadas: lençol e dois sacos impermeáveis com zíper, da seguinte forma:

- $1^{\text {a }) ~ E n r o l a r ~ o ~ c o r p o ~ c o m ~ l e n c ̧ o ́ i s ; ~}$

- $\left.2^{a}\right)$ Colocar o corpo em saco impermeável (preservando a posição anatômica);

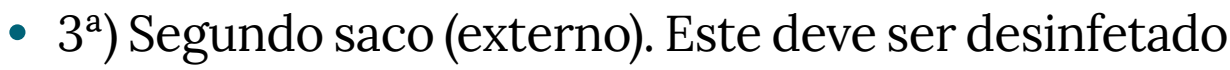
com álcool a 70\%.

- Identificar o saco externo de transporte com nome completo do falecido e informação relativa ao risco biológico: COVID-19, agente biológico classe de risco 3.

- Todos os materiais utilizados devem ser descartados como resíduos infectantes do Grupo A1 - Nível de risco III.

- Retirar todos os EPIs (seguir sequência de desparamentação).

- Higiene das mãos.

- Os funcionários que realizarem o transporte para o caixão devem equipar-se com luvas, avental impermeável e máscara cirúrgica.

- O corpo deve ser acomodado em urna (urnas habituais poderão ser utilizadas) a ser lacrada antes da entrega aos familiares ou responsáveis.

- Deve-se limpar a superfície da urna lacrada com álcool a $70 \%$ ou outro desinfetante indicado para esse fim.

- Depois de lacrada, a urna não deve ser aberta.

- Os falecidos devido à COVID-19 podem ser enterrados ou cremados. No caso de cremação, dois médicos devem assinar e identificar o CRM na declaração de óbito.

- O corpo não deve ser embalsamado.

- Os funerais devem ser evitados. Se ainda assim forem realizados, necessitam de algumas precauções (como na Figura 7). 
Figura 7 - Precauções em caso de funerais de suspeitos COVID-19.

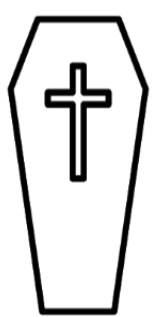

A urna funerária deve ser mantida fechada durante todo o tempo.

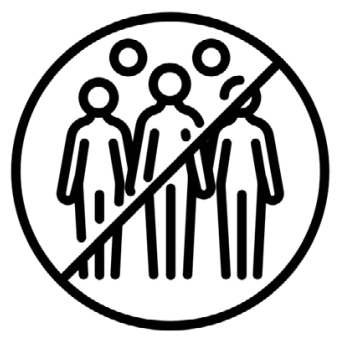

Orienta-se limitar o velório a no máximo

10 participantes para evitar aglomerações. Se necessário, adotar sistema de rodízio externo.

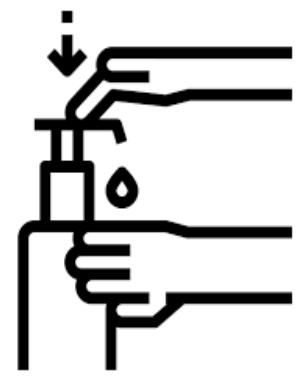

Disponibilizar água, sabão, papel toalha e álcool em gel a $70 \%$.

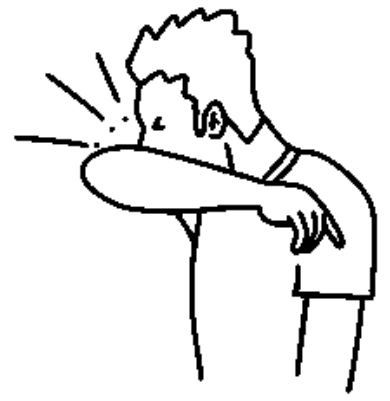

Não permitir a participação de pessoas com sintomas respiratórios. Caso seja

imprescindível, a mesma deve utilizar máscara cirúrgica, não ter contato físico com os demais e permanecer o mínimo possível.

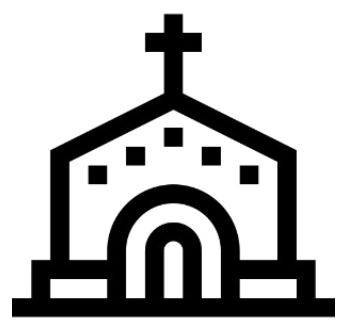

Devem acontecer preferencialmente em capelas mortuárias. Funerais em domicílio não são recomendados.

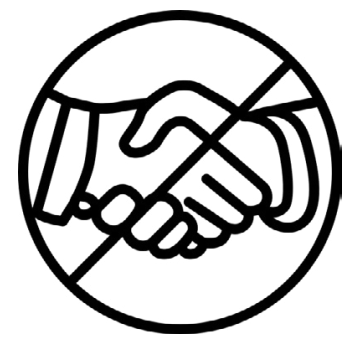

Evitar qualquer tipo de contato físico, como apertos de mão, beijos ou abraços. Manter uma distância mínima de 2 metros das outras pessoas.

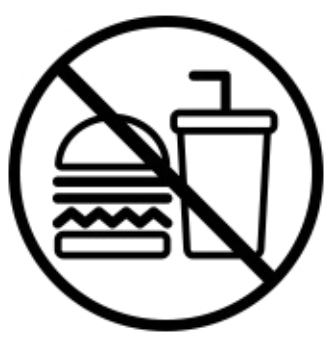

Não permitir a disponibilização de alimentos. No caso de bebidas, não permitir compartilhamento de copos.

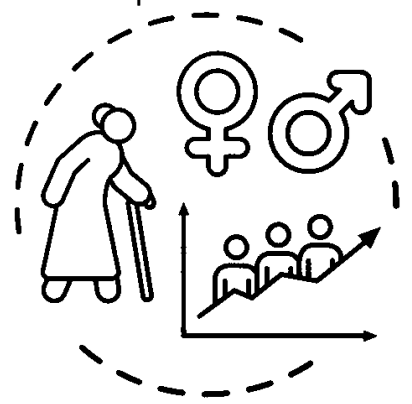

Recomenda-se fortemente que as pessoas que fazem parte do grupo de risco permaneçam em quarentena voluntária e não participem de funerais.

Fonte: Os autores. 


\section{Ocorrência hospitalar}

- O médico, após atestado o óbito e registrado em prontuário, entrará em contato com o familiar ou responsável e solicitará o comparecimento no hospital.

- Colocar o biombo, se o quarto não for privativo.

- Desligar todos os aparelhos e equipamentos.

- Reunir os materiais necessários e encaminhar ao leito.

- Posicionar a cama com a cabeceira levemente elevada, para minimizar os refluxos gastroesofágico e sanguíneo.

- Devem ser removidos do corpo todos os dispositivos, cateteres e drenos com auxílio de tesoura ou bisturi, se necessário.

- Higienizar e tapar ou bloquear os orifícios de drenagem de feridas e punção de cateter com cobertura impermeável.

- Aspirar secreções naso-orofaríngeas, a fim de reduzir o sangue pela boca e nariz.

- Fixar esparadrapo no tórax do paciente contendo informações: nome, número do prontuário, número do cartão nacional de saúde, data de nascimento, nome da mãe e CPF.

- Manter a identificação do paciente (pulseira).

- Limitar o reconhecimento do corpo a um único familiar ou responsável, que deve ser orientado a não se aproximar do corpo. Quando necessário à aproximação, o familiar ou responsável deverá fazer uso de avental de proteção impermeável, máscara cirúrgica e luvas.

- Se o local tiver estrutura, o reconhecimento poderá ser realizado por meio de fotografias.

- Passar o corpo da cama para maca. 
- A maca de transporte do corpo deve ser utilizada, exclusivamente para esse fim, de fácil limpeza e desinfecção, e sem colchão.

- Retirar luvas.

- Higienizar as mãos com álcool a 70\%.

- Colocar luvas conforme procedimento.

- Entregar aos familiares os pertences do paciente.

- Solicitada a presença do serviço social para questionar se haverá cremação, deve-se providenciar assim a assinatura da DO por um segundo médico.

- Realizar a limpeza e desinfecção terminal dos equipamentos do leito.

- Solicitar à equipe de higienização a limpeza terminal do leito.

- Realizar as anotações de enfermagem, constando a data e horário do óbito, nome do médico que constatou o óbito, descrição dos cuidados realizados, todos os sinais externos e marcas de nascença, tatuagens, órteses e próteses que possam identificar o corpo e os horários da transferência ao morgue.

Durante os cuidados com corpos de casos suspeitos ou confirmados de COVID-19, devem estar presentes no quarto ou qualquer outra área apenas os profissionais estritamente necessários (todos com EPI).

Os EPIs recomendados para toda a equipe que maneja os corpos nessa etapa são: gorro, óculos de proteção ou protetor facial, avental impermeável de manga comprida, máscara cirúrgica, luvas e botas impermeáveis, conforme mostrado na Tabela 2. 
Tabela 2 - Equipamentos de Proteção Individual (EPIs) recomendados para toda a equipe que manejar corpos de casos suspeitos ou confirmados de COVID-19.
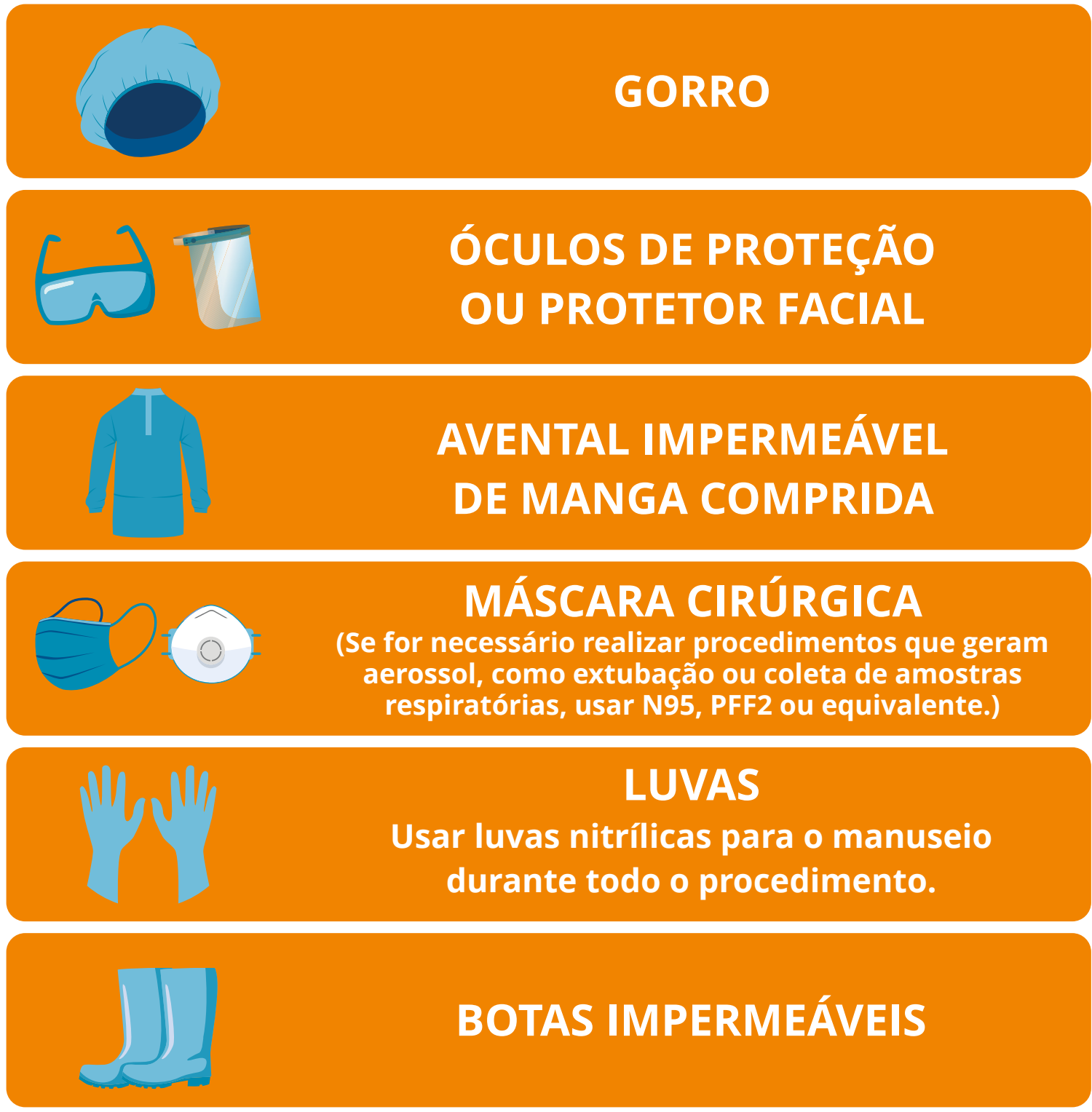

Fonte: Os autores.

Além disso, devemos remover os tubos, drenos e cateteres do corpo com cuidado, devido à possibilidade de contato com os fluidos corporais, descartando imediatamente os resíduos perfurocortantes em recipientes rígidos, providos de tampa, resistentes à punctura, ruptura, vazamento e identificados com símbolo infectante e a inscrição "resíduo perfurocortante". 
Ademais, deve-se higienizar e tapar ou bloquear os orifícios de drenagem de feridas e punção de cateter com cobertura impermeável, bem como limpar as secreções nos orifícios oral e nasais com compressas e tapar ou bloquear orifícios naturais (boca, nariz, ouvido, ânus) para evitar extravasamento de fluidos corporais, como evidenciado na Figura 11. Os profissionais devem manipular o corpo o mínimo possível e evitar procedimentos que gerem gases ou extravasamento de fluidos corpóreos.

Figura 8 - Cuidados em relação ao manejo de corpos no ambiente hospitalar.

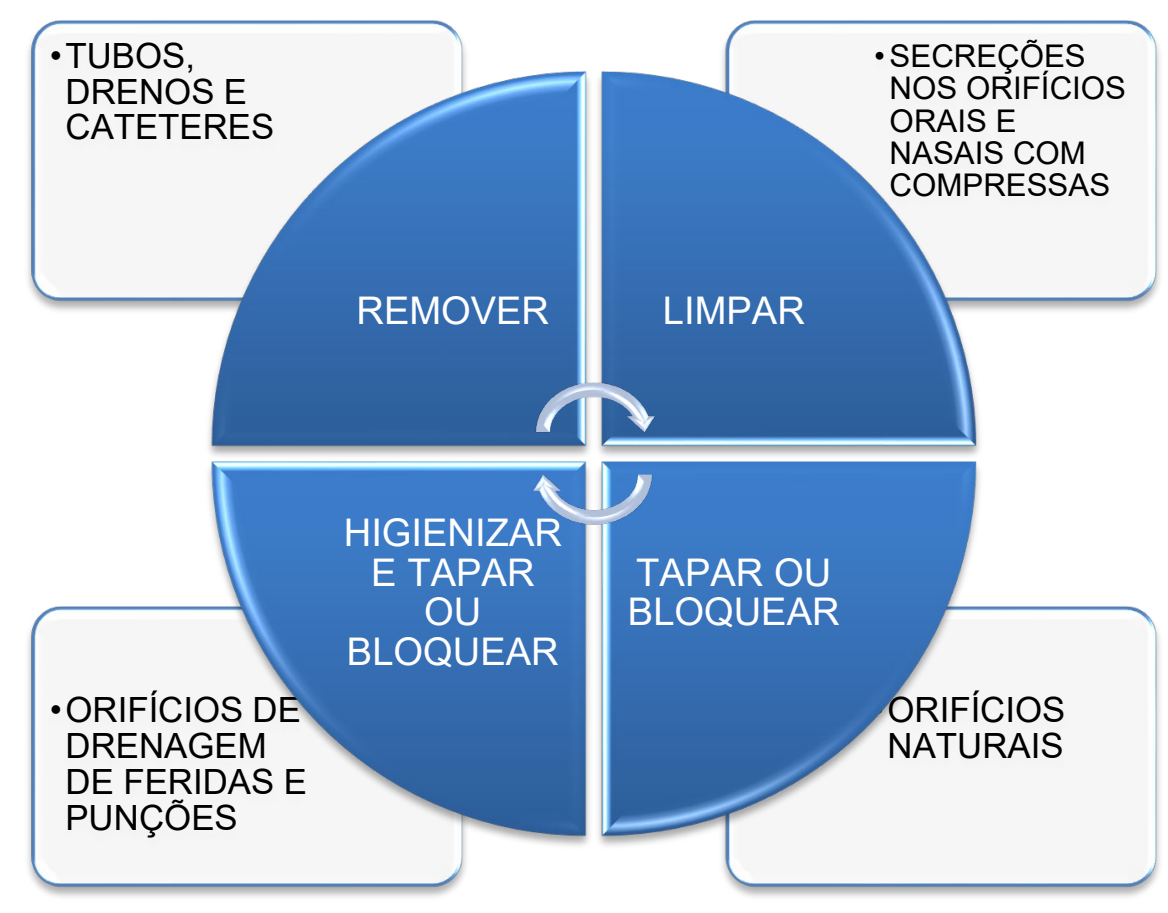

Fonte: Os autores.

O reconhecimento do corpo deve ser limitado a um único familiar ou responsável, de preferência que não tenha contato direto com o corpo, mantendo uma distância de dois metros entre eles. Quando houver necessidade de aproximação, o familiar ou responsável deverá fazer uso de máscara cirúrgica, luvas e aventais de proteção. Ainda é sugerido que, dependendo do caso, esse reconhecimento possa ser realizado por meio de fotografias, evitando contato ou exposição. 
Figura 9 - Reconhecimento por familiar ou responsável

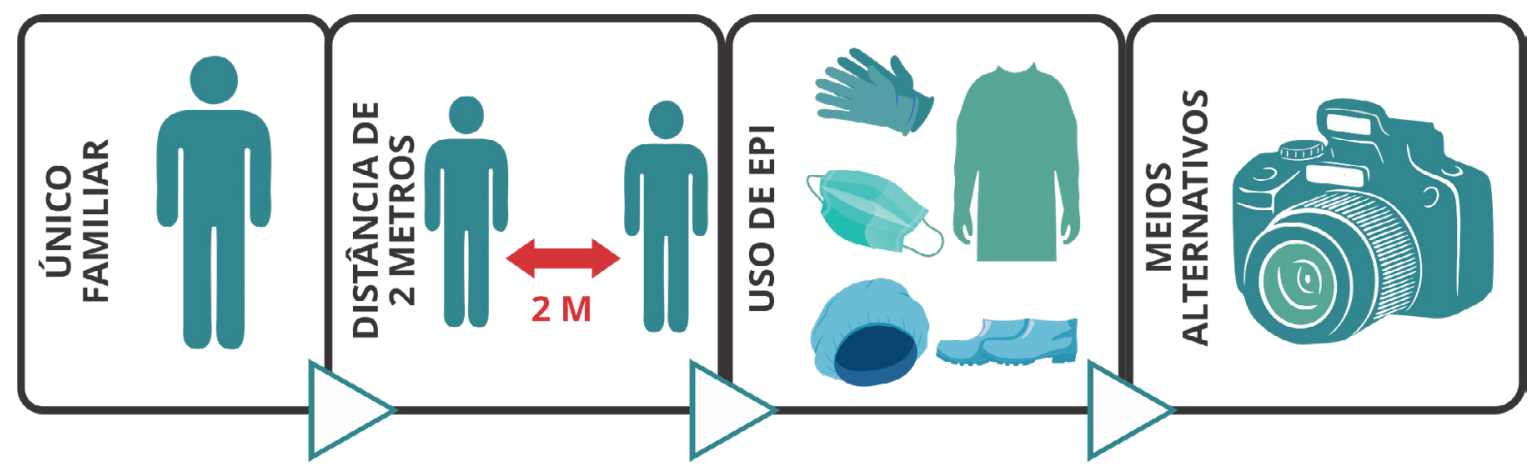

Fonte: Os autores.

É recomendado embalar o corpo e isso deve ocorrer ainda no local do óbito, sendo que a embalagem deve conter três camadas se possível: primeiro enrolar o corpo com lençóis, depois colocar o corpo em saco impermeável próprio (o qual deve impedir que haja vazamento de fluidos corpóreos) e em seguida, colocar o corpo em um segundo saco (externo) e desinfetar com álcool a 70\%, solução clorada de $0,5 \%$ a $1 \%$ ou outro saneante regularizado pela Anvisa, compatível com o material do saco. Por fim, deve-se colocar a etiqueta com a identificação do falecido e evitar mexer no corpo após a embalagem.

Figura 10 - Embalagem do corpo no local de óbito

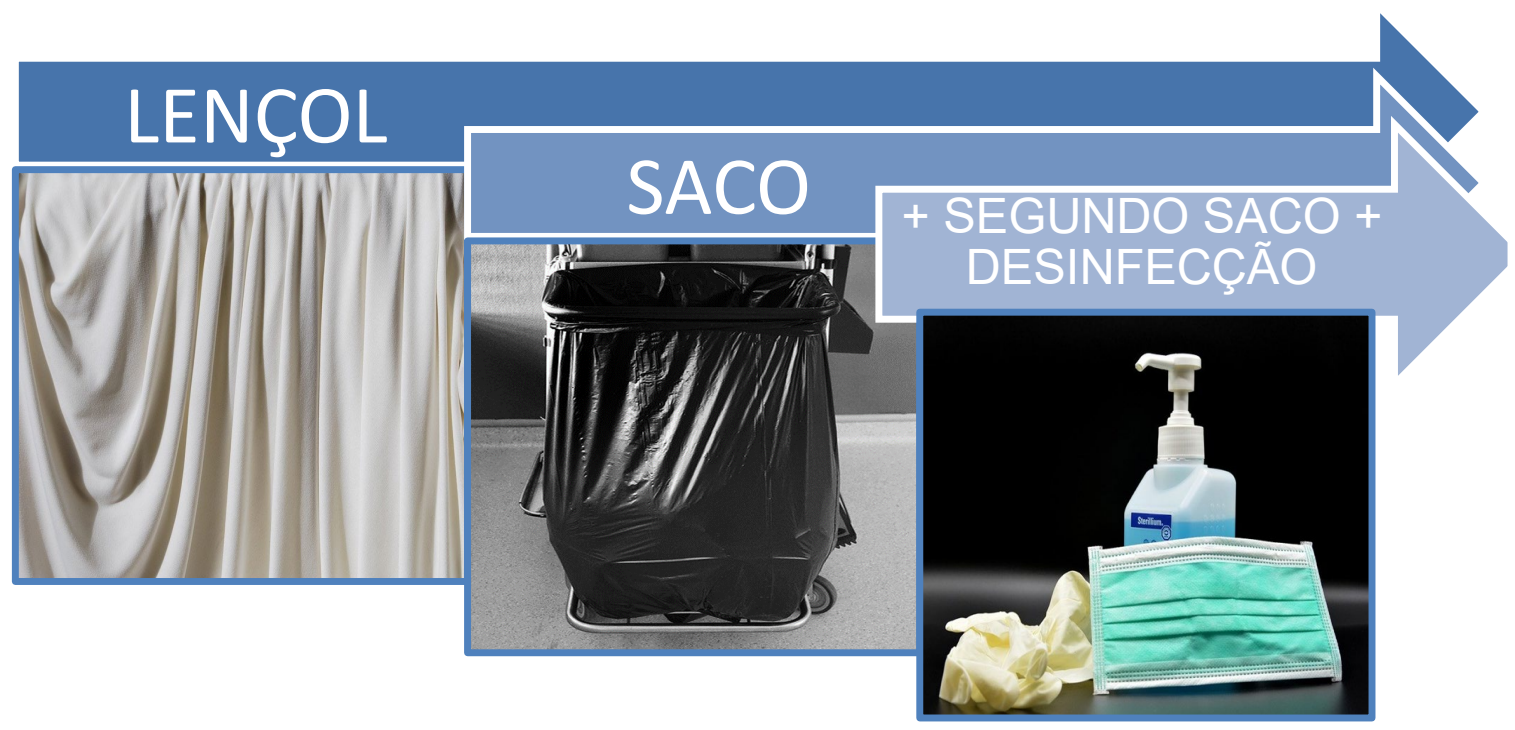

Fonte: Os autores.

A identificação do corpo deve conter, preferencialmente, o nome, número do prontuário, número do Cartão Nacional de Saúde (CNS), data 
de nascimento, nome da mãe e CPF, utilizando-se o esparadrapo, com letras legíveis, fixado na região torácica. Além disso, é essencial descrever no prontuário dos pacientes os dados referentes a todos os sinais externos, como marcas de nascença, tatuagens, órteses e próteses que possam auxiliar na identificação do indivíduo. Recomenda-se também registrar o saco externo de transporte com informação relativa ao risco biológico: COVID-19, agente biológico classe de risco 3.

Figura 11 - Identificação do corpo

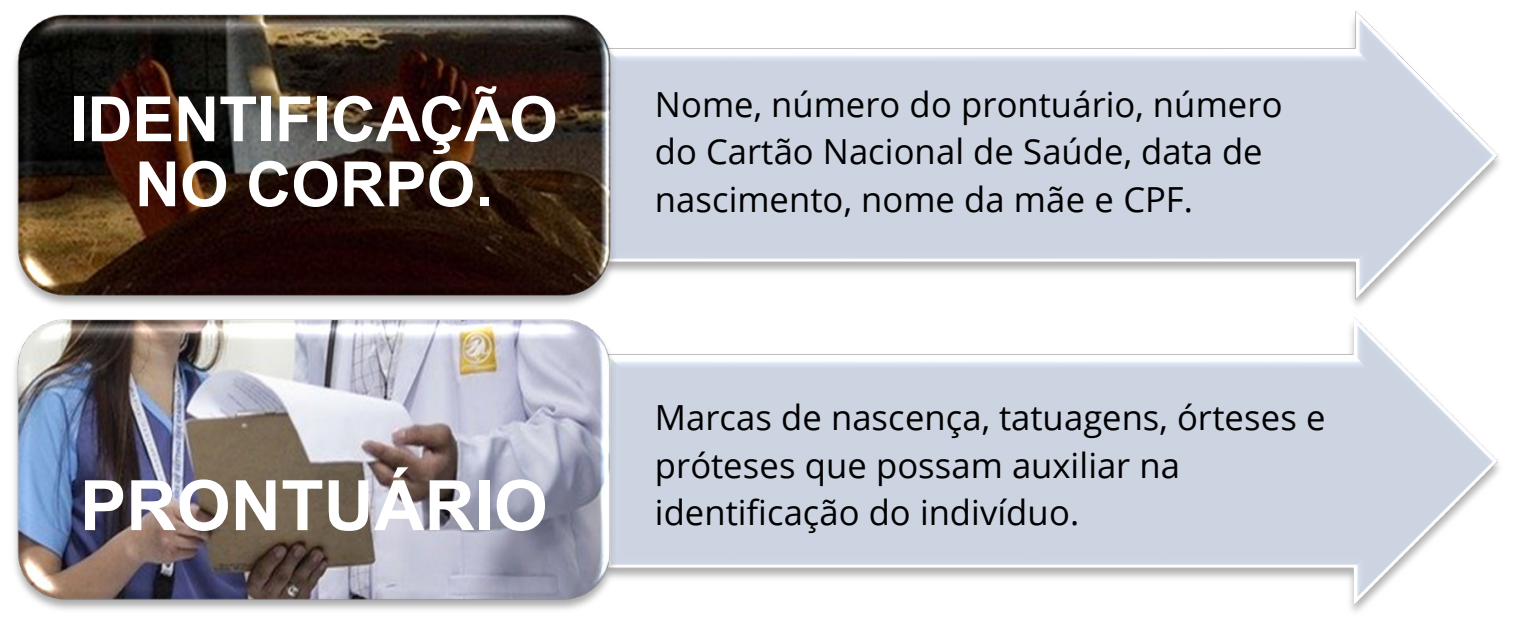

Fonte: Os autores.

O serviço funerário ou de transporte deve ser informado de que se trata de vítima de COVID-19, agente biológico com classe de risco 3. Nesse entender, para o transporte do corpo recomenda-se utilizar uma maca específica para esse fim, porém em caso de reutilização de maca, deve-se desinfetá-la com álcool a 70\%, solução clorada 0,5\% a $1 \%$ ou outro saneante regularizado pela Anvisa. Não é necessário veículo especial para transporte do corpo e também não há necessidade de uso de EPI por parte dos motoristas dos veículos que transportarão o caixão com o corpo.

No necrotério, é recomendado alocar o corpo em compartimento refrigerado e sinalizado como COVID-19, agente biológico classe de risco 3. Não é recomendado realizar tanatopraxia, formolização ou embalsamamento do corpo, que deve ser acomodado em urna a ser lacrada, cuja superfície foi limpa com solução clorada $0,5 \%$, antes da entrega aos familiares ou responsáveis. As urnas habituais poderão ser 
utilizadas sem que sejam tomadas medidas adicionais, como o uso de urna de zinco. Enfim, depois de lacrada, a urna não deverá ser aberta.

Figura 12 - Sequência de transporte do corpo

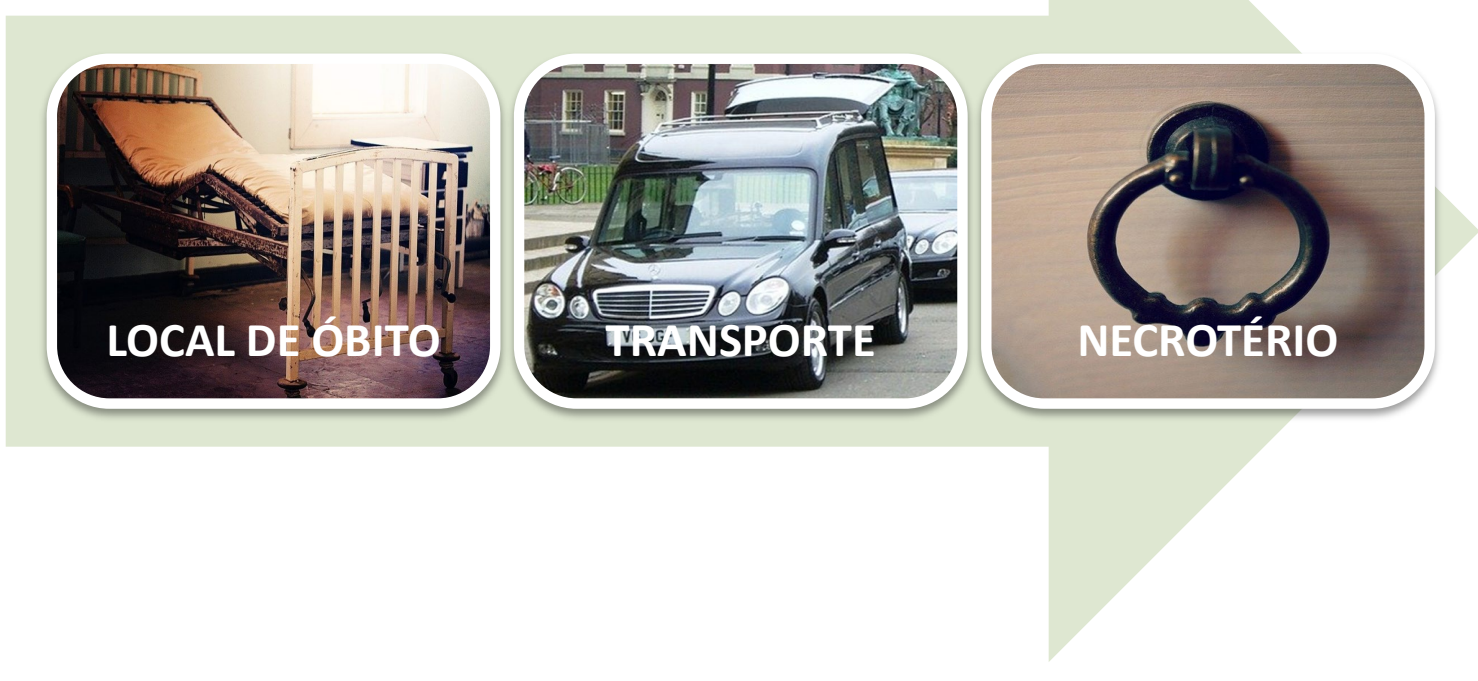

Fonte: Os autores.

Todo profissional que atua, seja no transporte, seja na guarda ou alocação do corpo devem adotar as medidas de precaução até o fechamento do caixão. Dessa maneira, após a manipulação do corpo, os funcionários devem retirar e descartar luvas, máscara, avental (se descartável) em lixo infectante. Além de higienizar as mãos com água e sabonete líquido (por 40 segundos) ou álcool a $70 \%$ (por 20 segundos) antes de colocar e depois de retirar os EPIs, os quais devem ser descartados como resíduos infectantes.

Vale ressaltar que todos os materiais utilizados devem ser descartados como resíduos infectantes do Grupo A1 - Nível de risco III. Desse modo, os resíduos e materiais que não puderem ser processados devem ser acondicionados em saco vermelho ou, na impossibilidade, em saco branco leitoso, que devem ser substituídos quando atingirem $2 / 3$ de sua capacidade ou pelo menos 1 vez a cada 48 horas e encaminhados para tratamento e disposição final ambientalmente adequada, por empresa especializada. 
Não é recomendado que pessoas acima de 60 anos, com comorbidades ou imunossuprimidas sejam expostas a atividades relacionadas ao manejo direto do cadáver. É também recomendado que sejam registrados nomes, datas e atividades de todos os trabalhadores que participaram dos cuidados, incluindo a limpeza ambiental, bem como de familiares ou outros que tenham tido contato com o falecido.

A limpeza desses locais deve atender os requisitos propostos na Nota Orientativa $\mathrm{n}^{\circ}$ 01/2020 (ANVISA, 2020) e não devem ser utilizados ar comprimido ou água sob pressão, ou qualquer outro método que possam gerar respingos ou aerossóis.

\section{Ocorrência domiciliar}

Em caso de ocorrência de óbito domiciliar, devem-se adotar os seguintes procedimentos:

- Uma equipe de saúde deve ser preparada para receber esse tipo de intercorrência.

- Aquele que reportou o óbito deverá ser orientado a não manipular o corpo.

- O médico deve se deslocar junto com a equipe para atestar o óbito.

- A equipe de vigilância em saúde deve ser avisada imediatamente.

- A equipe de saúde deve realizar o preparo do corpo no local e embalá-lo nas três camadas (lençol e dois sacos impermeáveis).

- Essa equipe aguardará a chegada do serviço funerário.

- Os familiares que residiam com o falecido devem receber orientações quanto à desinfecção do ambiente e isolamento domiciliar. 


\section{REFERÊNCIAS BIBLIOGRÁFICAS}

BRASIL. Ministério da Saúde. Secretaria de Vigilância em Saúde. Departamento de Análise em Saúde e Vigilância de Doenças não Transmissíveis. Manejo de corpos no contexto do novo coronavírus COVID-19. Brasília, 2020.

AGÊNCIA NACIONAL DE VIGILÂNCIA SANITÁRIA (ANVISA). Nota Técnica Pública CSIPS/GGTES/ANVISA Nº 01/2020. Orientações para a prevenção e o controle de infecções pelo novo coronavírus (SARSCoV-2) em instituições de acolhimento. Disponível em < https:// www20.anvisa.gov.br/segurancadopaciente/index.php/alertas/item/ nota-tecnica-publica-csips-ggtes-anvisa-n-01-2020>. Acesso em: 16 $\operatorname{dez} 2020$.

PARANÁ. Secretaria do Estado da Saúde do Paraná. Limpeza e desinfecção de ambientes. Nota orientativa ${ }^{\circ}$ 01, 2020. Disponível em: https://www.saude.pr.gov.br/sites/default/arquivos_restritos/files/ documento/2020-09/NO_01_LIMPEZA_E_DESINFECCAO_DE_ AMBIENTES_V2.pdf Acesso em: 16 dez 2020.

PARANÁ. Secretaria do Estado da Saúde do Paraná. Recomendações gerais para manejo de óbitos suspeitos e confirmados por COVID-19 no estado do Paraná. Nota orientativa $n^{\circ} 19,2020$. Disponível em: <saúde. gov.br/images/pdf/2020/marco/25/manejo-corpos-coronavirusversao1-25mar20-rev5.pdf>. Acesso em: 16 dez 2020. 


\section{O REGISTRO (ASSENTO) DE ÓBITO NAS SERVENTIAS DE REGISTRO CIVIL DAS PESSOAS NATURAIS}

Denise Damo Comel Carlos Eduardo Coradassi

O registro civil das pessoas naturais é um serviço prestado pelas serventias do foro extrajudicial (mais conhecidas como Cartórios De Registro Civil) e tem por objetivo garantir a autenticidade, a segurança e a eficácia dos atos jurídicos que dizem respeito ao estado da pessoa natural. É um serviço que funciona ininterruptamente, todos os dias da semana, inclusive sábados, domingos e feriados, conforme estabelece o art. $8^{\circ}, \S$ único, da Lei $n^{\circ}$ 6.015/73 (BRASIL, 1973), conhecida como Lei dos Registros Públicos (LRP).

É no registro civil das pessoas naturais que são registrados, dentre outros, os nascimentos, os casamentos e os óbitos - este último, no caso, é aquele que nos interessa.

Conforme preceitua o caput do art. 77 da Lei dos Registros Públicos, o registro de óbito é feito "em vista do atestado médico, se houver no lugar, ou em caso contrário, de duas pessoas qualificadas que tiverem presenciado ou verificado a morte" (BRASIL, 1973).

Esse atestado médico a que se refere a lei é a Declaração de Óbito (DO), que consiste em um formulário padronizado, emitido exclusivamente pelo Ministério da Saúde, em 3 vias de igual teor, e é o principal documento para que se proceda a lavratura do registro do óbito.

A hipótese legal de exceção, de ser o óbito declarado por "duas pessoas qualificadas que tiverem presenciado a morte" se não houver médico no lugar, deve ser interpretada restritivamente, ou seja, somente no caso de não haver possibilidade material de acesso ao serviço de saúde, seja público ou particular. Tal exceção não se aplica aos municípios 
com 100\% de cobertura pelo Sistema Único de Saúde (SUS), tal como Ponta Grossa-PR (local onde este Manual foi produzido), pois toda a sua extensão ocorre cobertura pelo Sistema Único de Saúde (SUS), até mesmo na zona rural e nos distritos. De qualquer localidade pode ser acionado o Serviço Médico de Urgência (SAMU) que, aliás, abrange os 12 municípios da $3^{\circ}$ Regional de Saúde no Paraná ( $\left.3^{\mathrm{a} R S}\right)$.

\section{Registro de óbito}

Se não houver médico ou impossibilidade de acesso a saúde,

o óbito pode ser declarado por "duas pessoas qualificadas que

tiverem presenciado a morte".

Porém, essa exceção não se aplica em municipios em que existe 100\% de cobertura pelo Sistema Único de Saúde (SUS).

Importante:

A responsabilidade pelo preenchimento da Declaração de Óbito é privativa do médico, seja integrante do serviço público de saúde, seja do serviço privado - basta que esteja no exercício regular da profissão.

Preenchidos os formulários da DO, uma de suas vias (a amarela) é entregue aos familiares do morto para que seja apresentada na serventia de registro civil, possibilitando assim a lavratura do registro (ou assento) de óbito.

O registrador, ao receber a Declaração de Óbito, procede a "qualificação do título" - quer dizer, analisa sua regularidade formal, verifica se está integralmente preenchida e assinada por um médico, também se há perfeita correspondência dos dados de identificação do falecido com os documentos que lhe são apresentados. Como documento oficial, a Declaração de Óbito não deve conter rasuras ou ressalvas, em qualquer 
uma de suas vias. Inclusive, na eventual hipótese de haver necessidade de correção ou de alteração do que nela consta, o próprio emissor do documento é quem deve promover o cancelamento da declaração, inclusive em suas 3 vias, com emissão de outra substitutiva.

Estando em ordem a Declaração de Óbito, identificado o apresentante conforme ordem legal de preferência prevista no art. 79, da LRP (BRASIL, 1973) e prestadas as demais informações de menção obrigatória no assento de óbito (como, por exemplo, filiação do falecido, estado civil, existência de filhos ou testamento), o registrador então lavra o registro do óbito, ao qual transporá com rigorosa fidelidade os dados que constam na Declaração de Óbito. Destaque-se que o registrador é vinculado ao que consta em referido documento, não podendo modificar ou suprimir qualquer das informações ali constantes, em hipótese alguma.

Lavrado o assento de óbito nos livros da serventia, expede-se então a chamada Certidão de Óbito- que é o expediente no qual o registrador, o qual tem fé pública, declara o teor do assento, ou seja, certifica que nos livros da serventia foi lavrado aquele óbito em particular, como cita o art. 16 da LRP (BRASIL, 1973). A certidão de óbito é o documento que serve de prova da morte para todos os fins de direito.

O registro de óbito deve ser providenciado dentro de 24 horas do falecimento, conforme o art. 78 da LRP (BRASIL, 1973), inclusive porque nenhum sepultamento pode ser feito sem apresentação da certidão de óbito, segundo o art. 77 da mesma Lei. Justamente por tal razão é que o serviço de registro civil das pessoas naturais é ininterrupto, ou seja, funciona inclusive sábados, domingos e feriados - com já se disse. Caso, por algum motivo relevante, não possa ser feito o registro imediatamente, a lei admite que ainda o seja no prazo de 15 dias, pelo art. 78, c/c art. 50 da LRP (BRASIL, 1973). Se mesmo dentro desse prazo não for realizado o registro, passará a depender de autorização judicial expressa para que se possa realizar.

Atualmente, em virtude da situação de pandemia da COVID-19, foi baixada a Portaria Conjunta 02/2020 do Conselho Nacional de Justiça e do Ministério da Saúde, (BRASIL, 2020) dispensando a apresentação da certidão de óbito para o sepultamento e diferindo o prazo de lavratura do assento, mas apenas na hipótese de ausência de familiares ou pessoas conhecidas do obituado ou em razão de exigência de saúde pública. 
Nesses casos, o sepultamento será admitido apenas com a apresentação da Declaração de Óbito devidamente preenchida e o assento de óbito terá o prazo de até 60 dias para ser providenciado.

Nos casos ordinários, em que o falecido é conhecido, há algum familiar presente e inexistente exigência de saúde pública, permanece o procedimento padrão, sem alteração de exceção.

Figura 13 - Ementa da Portaria Conjunta No 2 de 28 de abril de 2020 do Conselho Nacional de Justiça e do Ministério da Saúde.

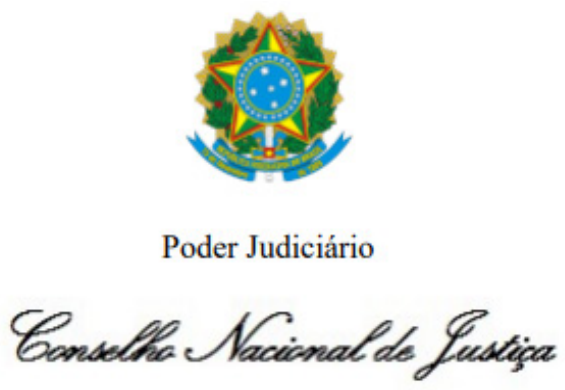

PORTARIA CONJUNTA N ${ }^{\circ}$ 2, DE 28 DE ABRIL DE 2020

Estabelece procedimentos excepcionais para sepultamento de corpos durante a situação de pandemia do Coronavirus, com a utilização da Declaração de Óbito emitida pelas unidades notificadores de óbito, na hipótese de ausência de familiares, de pessoa não identificada, de ausência de pessoas conhecidas do obituado e em razão de exigência de saúde pública, e dá outras providências.

Fonte: Conselho Nacional de Justiça, 2020.

\section{Referência bibliográficas}

BRASIL. (a, b, c d?) Lei no 6.015 de 31 de dezembro de 1973. Dispõe sobre os registros públicos e dá outras providências. Disponível em <http:// www.planalto.gov.br/ccivil_03/leis /L6015compilada.htm>. Acesso em 20 set. 2020.

BRASIL. (a, b, c, d?) Conselho Nacional de Justiça e Ministério da Saúde. Portaria Conjunta $\mathrm{n}^{\circ} 2$, de 28 de abril de 2020. Estabelece procedimentos excepcionais para sepultamento de corpos durante a situação de pandemia do Coronavírus, com a utilização da Declaração de Óbito emitida pelas unidades notificadores de óbito, na hipótese de ausência de familiares, de pessoa não identificada, de ausência de pessoas conhecidas do obituado e em razão de exigência de saúde pública, e dá outras providências. Dísponível em: https://www.conjur.com.br/dl/portariaconjunta-28-abril-2020-cnj.pdf Acesso em 20 set. 2020. 


\title{
DISCUSSÕES SOBRE ÓBITOS NA PANDEMIA COVID-19: ESTRATÉGIAS DE ENFRENTAMENTO E CUIDADO DE FAMILIARES E PROFISSIONAIS DE SAÚDE
}

\author{
Hélcio dos Santos Pinto \\ Estela Baldani Pinto \\ Lara Simone Messias Floriano \\ Ricardo Zanetti Gomes
}

O momento histórico que enfrentamos atualmente em âmbito mundial está demandando reflexões sobre diversos pontos em nossa sociedade. Dentre essas reflexões, observamos o modo de nos relacionarmos com as pessoas em nossas conexões interpessoais e sociais. Estamos repensando a nossa relação saúde-doença. Vemo-nos também privados do direito de ir e vir. Enfrentamos a situação de que, nossos momentos de lazer reduziram-se a atividades seguras e majoritariamente domiciliares. Alterações importantes ocorreram em nossos campos laborais e nos vemos repensando a relação que estabelecemos com nós mesmos (NOAL; PASSOS; FREITAS, 2020).

Uma grande parcela da população mundial está tendo a possibilidade de assistir à pandemia da COVID-19 em suas televisões, celulares e demais aplicativos eletrônicos que, por mais informativos que sejam, conferem uma distância segura em relação ao vírus. A realidade é diferente nos hospitais referenciados para o tratamento dos casos confirmados e suspeitos de infecção pelo vírus da COVID-19. O cotidiano dos hospitais atualmente se apresenta em ritmo acelerado, aliado a preocupações constantes sobre a possibilidade do colapso do sistema de saúde. Nesse cenário, os profissionais de saúde realizam longas jornadas de trabalho com o intuito de preservar a vida das pessoas acometidas 
pelo vírus (TEIXEIRA et al., 2020). Esses agentes dividem seu cotidiano entre o isolamento social durante suas folgas e longas horas de plantões, cuja jornada não se pode antever.

Sobre esses profissionais de saúde, nota-se que cada um atua de forma intensa, dentro de sua área de saber e especialidade, buscando o aperfeiçoamento constante, realizando produções científicas e acadêmicas, sem deixar de cumprir seus preceitos éticos. Dentre os profissionais de saúde atuando na linha de frente do enfrentamento e cuidado, temos médicos, enfermeiros, fisioterapeutas, psicólogos, assistentes sociais, fonoaudiólogos, entre outros. Tais profissionais verificam que precisam atualizar seus conhecimentos técnicos ao mesmo tempo em que atuam em suas áreas de especialização.

Sabemos que a rotina hospitalar e o cuidado intensivo demandam esforços importantes visando à manutenção de vida dos pacientes hospitalizados. É com esse propósito que os profissionais de saúde assumem seus plantões diariamente em todo o território nacional, trabalhando intensamente para o controle dos sintomas de correntes da doença, pois até a construção deste manual ainda não contamos com uma cura para o vírus. Os esforços dos agentes têm o intuito de preservar a vida, contornar sintomas e devolver o sujeito funcional ao seu meio social, familiar e laboral, porém, uma parcela dos pacientes não consegue vencer a COVID-19 e acaba evoluindo a óbito durante a internação hospitalar (NOAL; PASSOS; FREITAS, 2020).

A morte faz parte da rotina hospitalar, porém, agora, sabendo que não existe vacina ou imunização eficaz para o vírus, ela se mostra mais imperativa, visto o grande número de infecções pelo vírus SARS-CoV-2. A forma de vivenciar a morte dentro dos hospitais demanda então mudanças importantes na rotina da instituição (NOAL; PASSOS; FREITAS, 2020). Por isso, este estudo foi pensado e dividido em categorias que tratam do tema "óbito por COVID-19", trazendo orientações e reflexões acerca desta forma de óbito para os profissionais. 


\section{Como é possível manter o enfrentamento da vivência de óbitos na pandemia COVID-19 por profissionais de saúde?}

O efeito dos óbitos suspeitos ou confirmados por COVID-19 demanda alterações importantes na organização da rotina hospitalar. Dentre essas alterações, notamos impactos na comunicação do óbito, informações relativas aos trâmites funerários e de reconhecimento do corpo pelos familiares. Dentre essas alterações, é pertinente que seja garantido o funcionamento institucional seguro, assim como a segurança e o acolhimento dos familiares dos pacientes que evoluem a óbito. A humanização se mostra como importante desafio durante este período, pois a internação dos pacientes suspeitos ou confirmados por COVID-19 demandam isolamento para o controle da disseminação do vírus. Essa característica também deve ser mantida no contexto do óbito (NOAL; PASSOS; FREITAS, 2020).

Recomenda-se que cada instituição realize diagnósticos e análises amplas, buscando identificar os recursos disponíveis e possibilidades dentro do contexto institucional que viabilizem o trabalho de forma direta, objetiva e segura, concentrando atenção em materiais e insumos, recursos humanos e profissionais capacitados, possibilidades estruturais e ambientais da instituição (NOAL; PASSOS; FREITAS, 2020).

Dentre as alterações pertinentes ao óbito no contexto da pandemia da COVID-19, serão descritas algumas recomendações no que tange à comunicação de óbito aos familiares, reconhecimento do corpo e trâmites funerários. Esses pontos rotineiramente ocorrem dentro da instituição hospitalar, porém neste contexto de pandemia indica-se que sejam realizados, em sua grande maioria, de forma remota, visando à diminuição da disseminação da doença (NOAL; PASSOS; FREITAS, 2020). Essas etapas devem ocorrer assim:

\section{A comunicação}

- A comunicação deve ocorrer de forma prioritariamente remota, neste momento de pandemia do vírus SARS-CoV-2. A comunicação pode ocorrer por meio de ligações de áudio e vídeo com os familiares, e é 
importante que se crie e estabeleça o vínculo desde o início da internação hospitalar, sempre com escuta ativa das dúvidas dos familiares a respeito do quadro clínico do paciente. No momento do óbito, o vínculo já deve ter sido estabelecido para que se possa ter uma comunicação clara ou com minimização de ruídos.

Figura 14 - Comunicação entre profissionais de saúde, familiares e paciente com COVID-19.
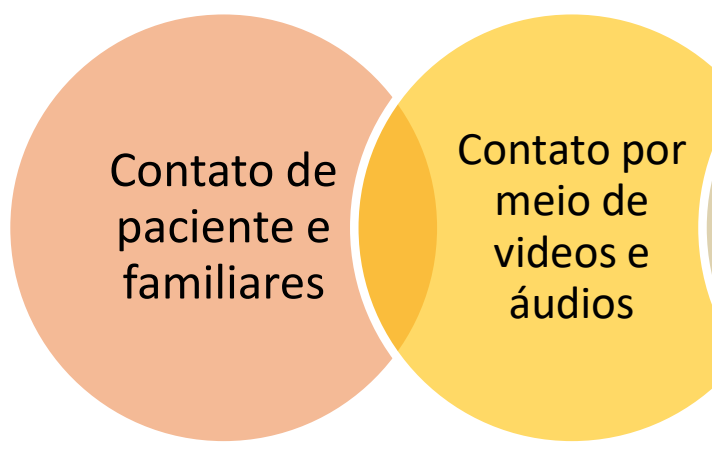
Criação de vinculo entre profissional da saúde e familares

Melhor comunicação no momento de óbito

Fonte: Os autores.

- É necessário que a equipe assistencial se prepare para o comunicado do óbito, dando preferência a contatar o familiar de referência, que está acompanhando a evolução da internação.

- O profissional que vai comunicar o óbito deve estar preparado para as possíveis dúvidas e questionamentos que o familiar possa trazer durante o comunicado. Assim, indica-se para esse profissional revisar o histórico de internação antes de iniciar a ligação, a fim de estar apto para responder quaisquer dúvidas e questionamentos.

- Durante a ligação, é importante usar discurso claro e objetivo, não deixando dúvidas sobre a ocorrência do óbito. 
Figura 15 - Modelo de comunicação virtual de óbitos.
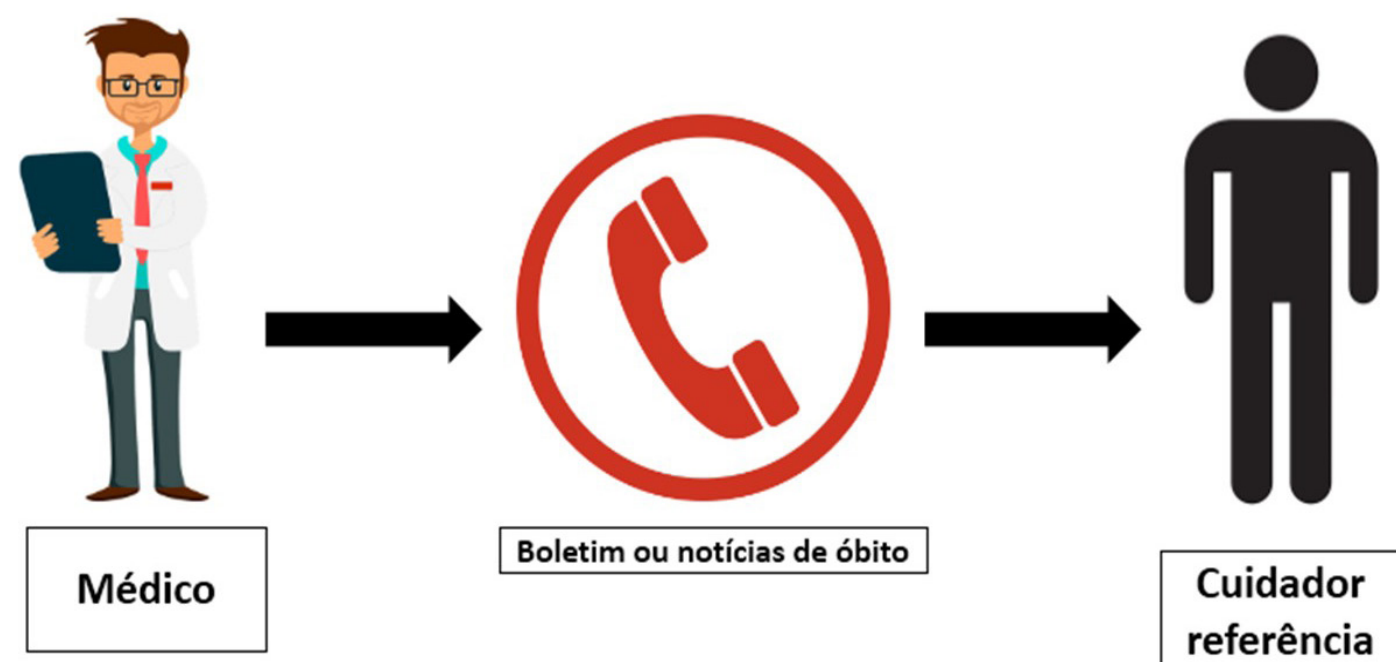

Cuidador referência

Fonte: Os autores.

Se possível, assegurar que o familiar de referência não está sozinho e possui suporte familiar de outros membros da família para este momento.

- É fundamental que o profissional responsável por comunicar o óbito esteja ciente de que reações emocionais variadas podem advir com o comunicado. Dentre elas: tristeza, raiva, ansiedade, barganha, e ainda outras. É pertinente ainda que o profissional esteja disposto a possibilitar tempo para a expressão dessas manifestações emocionais, tendo em mente que elas podem não cessar durante o comunicado, pois é o momento em que se inicia o processo de luto e que os familiares devem elaborar em tempo próprio.

- Uma vez que o profissional perceba que os familiares compreenderam a ocorrência do óbito e tiveram o tempo necessário para esclarecer dúvidas e expressar suas emoções, devem ser repassados aos profissionais do serviço social para que estes últimos possam orientar sobre os trâmites funerários. 


\section{Trâmites funerários}

- As orientações para os trâmites funerários também sofreram importantes alterações com a pandemia de COVID-19, sendo que neste cenário atual também devem ser realizadas de forma remota.

- Indica-se que os profissionais responsáveis por estas orientações também estejam cientes das expressões emocionais já comentadas anteriormente, que podem também ocorrer durante o repasse destas informações sobre os trâmites funerários.

- Deve certificar-se de que o contato é feito com o familiar de referência, assim como de que ele mantém sua rede de apoio no momento das orientações.

- Deve-se utilizar a escuta ativa para as dúvidas pertinentes e usar linguagem clara e acessível para minimizar os ruídos de comunicação que possam surgir neste momento.

- Os óbitos por suspeita e confirmação de infecção pelaCOVID-19 demandam uma organização funerária particular. Dentre elas, existem as recomendações de não ocorrer em velórios e cerimônias de despedidas. Existe então um impasse, pois esses momentos são um fator importante no auxílio da elaboração do luto entre os familiares.

- Quanto à impossibilidade da realização de velórios, os profissionais devem estar cientes de que podem enfrentar resistência por parte dos familiares. Novamente, as orientações precisam ser reafirmadas do motivo da ocorrência de enterros breves e diretos.

- É imprescindível que os profissionais estejam munidos de informações técnicas e éticas, a fim de controlarem e prevenirem a disseminação do vírus SARS-CoV-2 como justificativa aos possíveis questionamentos trazidos por profissionais. 


\section{Reconhecimento do corpo}

- É pertinente atentar para o momento de reconhecimento do corpo, uma vez que este pode ser o único momento de contato dos familiares com o paciente, caso seja possível, dentro da realidade da instituição.

- Indica-se que a instituição padronize a sua forma de viabilizar o reconhecimento do corpo, de acordo com as suas possibilidades de garantir a segurança dos familiares, bem como, dos profissionais envolvidos no processo.

- Caso a equipe opte pelo reconhecimento do corpo nas dependências da instituição, é necessário que haja protocolo de funcionamento interno para essa ocorrência. Indica-se que aconteça com no máximo dois familiares, a fim de que possam prestar suporte e auxílio emocional um ao outro, de forma mútua. A instituição deve fornecer equipamentos de proteção individual adequados para os familiares e realizar o reconhecimento do corpo de forma breve e objetiva, prestando informações necessárias e pertinentes aos familiares presentes sobre a forma de funcionamento institucional antes de acontecer o reconhecimento do corpo.

- Caso a equipe opte pelo reconhecimento do corpo de forma remota, indica-se que a equipe acesse o familiar de referência por meio de vídeo chamada, a fim de garantir que o corpo é de fato do paciente em questão e certificando-se da resposta afirmativa por parte dos familiares. 


\section{Quais são as possibilidades de acolhimento dos familiares de vítimas de óbito por suspeita ou confirmação de COVID-19 em meio à pandemia?}

Um fator importante e desafiador para os profissionais de saúde é o acolhimento efetivo e humanizado dos familiares dos pacientes internados em isolamento em alas destinadas ao tratamento da suspeita ou confirmação pela infecção do vírus SARS-CoV-2. Para isso, indica-se que cada instituição, dentro de sua realidade e contexto, possa, por meio de profissionais qualificados, viabilizar um momento de escuta e auxílio a esses familiares, priorizando também o olhar psicossocial, com o objetivo de manter a saúde mental deles (NOAL; PASSOS; FREITAS, 2020). Novamente recomenda-se o acesso aos familiares de forma precoce, preconizando-se inclusive que sejam contatados no início da internação hospitalar.

Quando ocorre um óbito com suspeita ou confirmação de COVID-19, tal ocorrência demanda uma forma de atuação à qual, até então, as instituições não estavam habituadas, devido à especificidade desses óbitos. A respeito dessas especificidades, a principal questão é sobre o momento do funeral, pois a indicação técnica é de funerais com número reduzido de pessoas, preferencialmente apenas com os familiares mais próximos, visando ao controle da disseminação da doença e ressaltando ainda que o velório daqueles pacientes que evoluíram a óbito com suspeita ou confirmação de COVID-19 não é recomendado pelos órgãos de saúde. Para tanto, foram feitas as orientações a seguir:

\section{Acolhimento remoto durante a internação}

- Indica-se que os profissionais responsáveis pelo atendimento psicossocial dos pacientes e familiares estejam preparados para realização de acolhimento e atendimentos de forma remota, por meio de chamadas de áudio e vídeo, a fim de ouvir e trabalhar com as angústias decorrentes da internação.

- Os profissionais devem criar um plano de atendimento e acompanhamento, de acordo com o estado clínico 
do paciente, acompanhando sua evolução durante a internação.

- É fundamental certificar-se sempre da gravidade e risco de óbito durante os atendimentos remotos, quando ocorrer tal possibilidade, para que os familiares estejam cientes dessas informações.

- Caso os profissionais identifiquem, durante o acompanhamento, acentuado prejuízo na qualidade de vida dos familiares, é necessário realizar a psicoeducação, a fim de garantir a manutenção da sua saúde física e emocional.

- Ainda, caso os profissionais identifiquem necessidade, que a rede de saúde mental do município seja acionada para realização de encaminhamentos pertinentes.

Figura 16 - Fluxograma de acompanhamento e atendimento por profissionais da saúde para paciente com COVID-19 e seus familiares

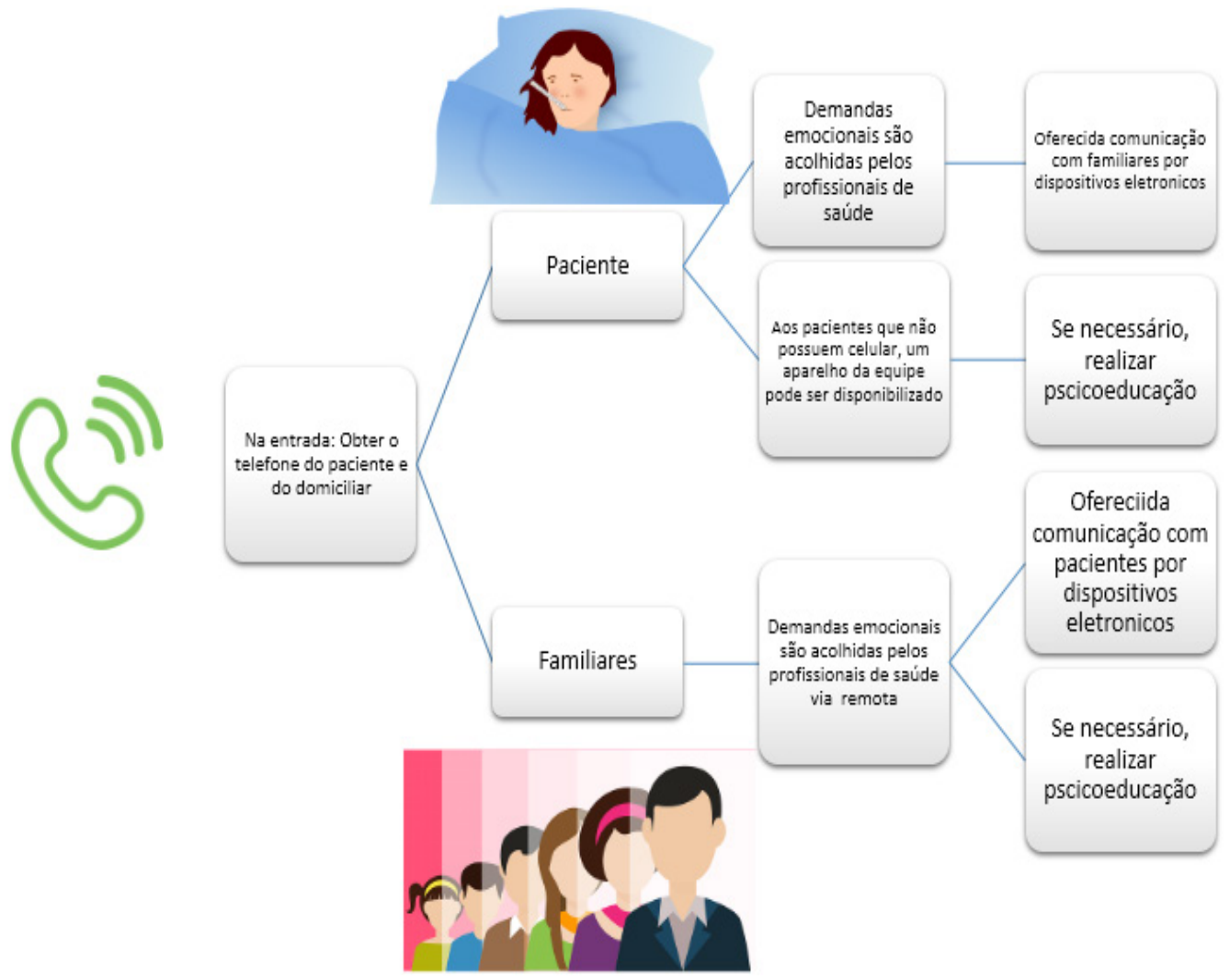

Fonte: Os autores. 


\section{Acolhimento em óbito}

- Aos profissionais responsáveis pelo acompanhamento psicossocial na instituição é recomendado seja uma equipe formada por profissionais de psicologia, devido à sua formação técnica e científica. Eles devem estar em constante comunicação com a equipe assistencial do paciente, pois, com a ocorrência do óbito, a equipe responsável pelo acompanhamento psicossocial intensifica o seu trabalho (CFP, 2020).

- Orienta-se aos profissionais, referentes ao acolhimento emocional, atuarem em tempo hábil e pertinente, não sendo recomendado o contato urgente e imediatamente após notícia de óbito.

- Salvo os casos em que a equipe assistencial identifique, durante o comunicado de óbito e orientação dos trâmites funerários, a urgência do acolhimento psicossocial, indica-se repassar o caso à equipe responsável.

- Durante o acolhimento em óbito, é pertinente que os profissionais busquem formas avaliativas, dentro de seus conhecimentos técnicos e científicos, de assegurar que os familiares possuam suas formas e estratégias para realização do processo de luto de forma saudável.

- Indica-se ainda, que se criem espaços futuros para acolhimento de demandas que não possam ser trabalhadas de forma remota, antevendo possíveis obstáculos na elaboração do luto saudável dentro do contexto da pandemia de COVID-19.

\section{Como cuidar de quem cuida?}

É fundamental ainda, que ocorra atenção e cuidado com a saúde mental dos profissionais de saúde responsáveis pelo enfrentamento e assistência aos pacientes com suspeita ou confirmação de COVID-19 (TEIXEIRA et al., 2020; NOAL; PASSOS; FREITAS, 2020). Todos os esforços 
estão despendidos para a manutenção da vida e a recuperação dos sintomas apresentados, porém, sabendo-se que uma parcela dos pacientes irá evoluir a óbito durante a internação, como dito anteriormente, recomenda-se que:

- Dentro da realidade e possibilidade institucional, é imprescindível que as instituições viabilizem espaços para o cuidado dos profissionais de saúde neste momento, uma vez que podem estar em contato diário com óbitos dentro deste contexto da pandemia de COVID-19.

- Indica-se que os canais de cuidado ocorram preferencialmente também de forma remota, a fim do controle da disseminação do vírus SARS-CoV-2, buscando dar voz para que os agentes de cuidado, que estão na linha de frente, possam expressar seus sentimentos e emoções decorrentes do contato direto com a morte.

- Importante possibilitar autonomia para que os profissionais de saúde, dentro de suas autopercepções, possam identificar dificuldades e falta de recursos de enfrentamento que possam vir a interferir em suas atuações profissionais e pessoais diárias, as quais podem ser decorrentes de pressões, sobrecarga de trabalho, angústias e medos, dentre outros motivos.

- Quando identificada a necessidade, seja pelo próprio profissional ou demais membros da equipe assistencial, indica-se também que seja acessada a rede de saúde mental do município para encaminhamentos cabíveis e pertinentes. 


\section{Por fim, é possível garantir à humanização frente à ocorrência de óbitos suspeitos ou confirmados por infecção do vírus COVID-19?}

É inegável que o contexto atual da pandemia de COVID-19 está trazendo diversas alterações no funcionamento dos serviços de saúde, pois tais consequências são percebidas e vividas diariamente dentro das instituições. É necessária a intensa revisão dos fatores e formas de humanização, para que o atendimento e o acesso aos serviços de saúde continuem acontecendo com qualidade e protagonismo dos seus usuários. Sabendo da importância e necessidade em humanizar cada vez mais o tratamento em saúde, os procedimentos utilizados até aqui podem não se encaixar de forma integral dentro desta nova realidade da pandemia da COVID-19 (NOAL; PASSOS; FREITAS, 2020). Para isso, sugere-se:

- Avaliação institucional constante sobre as possibilidades de atuação que abram espaço para o protagonismo dos usuários.

- Avaliação constante sobre a atuação dos profissionais, tendo claros e definidos os limites encontrados quanto a sua atuação e às possibilidades institucionais.

- Adaptação constante e diária frente às demandas e particularidades de cada caso, respeitando os protocolos institucionais vigentes, a fim de assegurar a segurança dos agentes envolvidos e o controle da disseminação da COVID-19.

- É pertinente que as equipes e os profissionais busquem novas formas, usando criatividade aliada à técnica e ao conhecimento científico de cara área de formação, para possibilitarem atendimento e acolhimento humanizados, objetivando a minimização dos danos que possam ocorrer durante as internações.

- Por fim, este momento demanda que as instituições priorizem sempre o atendimento interdisciplinar, afinando a comunicação entre equipe e objetivando a atuação por meio de protocolos cabíveis. 


\section{Referências bibliográficas}

CONSELHO FEDERAL DE PSICOLOGIA (CFP). Diário Oficial da União. Resolução no 4, de 26 de março de 2020. Disponível em: https://www.in.gov.br/en/web/dou/-/resolucao-n-4-de-26-demarco-de-2020-250189333\#: :text=Disp\%C3\%B5e\%20sobre\%20 regulamenta\%C3\%A7\%C3\%A3o\%20de\%20servi\%C3\%A7os,a\%20 pandemia\%20do\%20COVID\%2D19.\&text=1\%C2\%BA\%20Esta\%20 Resolu\%C3\%A7\%C3\%A3o\%20regulamenta\%20os,de\%20pandemia\%20 do\%20COVID\%2D19 Acesso em: 16 de dez de 2020.

NOAL, D. DA S.; DAMÁSIO, F.; FREITAS, C. M. (Orgs.) Recomendações e orientações em saúde mental e atenção psicossocial na COVID-19. Rio de Janeiro: Fiocruz, 2020. Recuperado de: <https://www.arca.fiocruz. $\mathrm{br} / \mathrm{handle} / \mathrm{icict} / 44264$.

TEIXEIRA, C. F. S. et al. A saúde dos profissionais de saúde no enfrentamento da pandemia de Covid-19. Ciência \& Saúde Coletiva, v. 25, n. 9. Rio de Janeiro: 2020.

ANVISA. Norma Técnica GVIMS/GGTES/ANVISA nº4/2020. Orientações para serviços de saúde: medidas de prevenção e controle que devem ser adotadas durante a assistência aos casos suspeitos ou confirmados de infecção pelo novo Coronavírus (SARS-Cov02). 2020.

BRASIL. Ministério da Saúde. Secretaria de Vigilância em Saúde. Departamento de Análise em Saúde e Vigilância de Doenças não Transmissíveis. Manejo de corpos no contexto do novo coronavírus COVID-19. Brasília, 2020.

PARANÁ. Secretaria do Estado da Saúde do Paraná. Diretoria de Atenção e Vigilância em Saúde. Nota orientativa $n^{\circ}$ 19: Recomendações gerais para manejo de óbitos suspeitos e confirmados por COVID-19 no estado do Paraná. Curitiba-PR, 2020. Disponível em: https://www.saude.pr.gov. br/sites/default/arquivos_restritos/files/documento/2020-06/ no_19_manejo_de_obitos_suspeitos_e_confirmados_por_doenca_ por_covid_19_v2.pdf. Acesso em: 16 dez 2020.

OLIVEIRA, A. Q. de. Rituais de luto e suas funções reconstrutoras em desastres. In: FRANCO, M. H. P. (org.). A intervenção psicológica em emergências: fundamentos para a prática. São Paulo: Summus, 2015. p. $229-258$. 
Sociedade Brasileira de Patologia. Orientações gerais de procedimentos durante evento de pandemia pela COVID19, 2020. Disponível em: $<$ http://www.sbp.org.br/orientacoes-gerais-de-procedimentosdurante-evento-de-pandemia-pela-covid19/> Acesso em: 16 dez 2020. 


\section{SOBRE OS AUTORES}

\section{Carlos Eduardo Coradassi}

Médico Veterinário

Doutor em Saude Única-UFPR

Professor Adjunto do Departamento de Enfermagem e Saúde

Pública da UEPG

\section{Fabiana Postiglione Mansani}

Farmacêutica e Bioquímica

Doutora em Ciências Bioquímicas-UFPR/Universidade de Coimbra

Professora Associada do Departamento de Medicina da UEPG

\section{Lislei Teresinha Preuss}

Assistente Social

Doutora em Serviço Social - PUC/RS

Professora Adjunta do Departamento de Serviço Social da UEPG

\section{Pollyanna Kássia de Oliveira Borges}

Cirurgiã-dentista

Doutora em Saúde Coletiva-UNIFESP

Professora Associada do Departamento de Enfermagem e Saúde Pública da UEPG

\section{Ricardo Zanetti Gomes}

Médico

Doutor em clínica cirúrgica-UFPR

Professor Associado do Departamento de Medicina da UEPG 


\section{Maria Dagmar da Rocha}

Enfermeira

Doutora em Ciências Famacêuticas-UEPG

Professora Adjunta do Departamento de Enfermagem e Saúde Pública da UEPG

\section{Erildo Vicente Muller}

Farmacêutico

Doutor em Saúde Coletiva-UNIFESP

Professor Associado Departamento de Enfermagem e Saúde Pública da UEPG

\section{Maria Cleonice Alves de Oliveira}

Técnica de Enfermagem da Vigilância Epidemiológica - $3^{\text {a }}$ Regional de Saúde Interlocutora dos Programas de Sistema de Informação de Mortalidade e Sistema de Nascidos Vivos.

\section{Caroline Soczek da Silva}

Enfermeira da Vigilância Epidemiológica $-3{ }^{\text {a }}$ Regional de Saúde

\section{Mauriceia Ribeiro de Souza}

Enfermeira Chefe da Seção de Vigilância Epidemiológica da $3^{\text {a }}$ Regional de Saúde

Especialista em Projetos Assistenciais em Enfermagem, Gestão em Saúde e Hemoterapia.

\section{Carolina Ribeiro Duarte}

Graduanda do curso de Bacharelado em Enfermagem pela UEPG Bolsista pela Fundação Araucária na $3^{\mathrm{a}} \mathrm{RS}$ - Ponta Grossa

\section{Denise Damo Comel}

Doutora em direito

Magistrada

Juíza de direito da $1^{\mathrm{a}}$ vara de família e sucessões, registros públicos e corregedoria do foro extrajudicial da comarca de ponta grossa

Professora na Escola da Magistratura do Paraná 


\section{Gabriela Benassi}

Acadêmica do $5^{0}$ ano do Curso de Medicina da UEPG

\section{Felício de Freitas Netto}

Acadêmico do $5^{0}$ ano do Curso de Medicina da UEPG

\section{Jacques Magnos Canossa Mantey}

Acadêmica do $4^{0}$ ano do Curso de Medicina da UEPG

\section{Jorge Felipe do Lago Pereira dos Santos}

Médico graduado pela UEPG

\section{Lorena Slusarz Nogueira}

Acadêmica do $5^{0}$ ano do Curso de Medicina da UEPG

\section{Lara Simone Messias Floriano}

Enfermeira

Doutora em Ciências pela Escola da Enfermagem - USP

Professora Adjunta do Departamento de Enfermagem e Saúde Pública-UEPG

\section{Estela Baldani Pinto}

Psicóloga

Mestranda em Ciências da Saúde-UEPG

Psicóloga do Programa UEPG Abraça-UEPG.

\section{Hélcio dos Santos Pinto}

Psicólogo - HURCG-UEPG

Especialista em Urgência e Emergência HC-UFPR

\section{Mateus Alves dos Santos}

Acadêmico do $4^{0}$ ano do Curso de Medicina da UEPG

\section{Barbara Leticia Rosa Pereira}

Acadêmica do $3^{0}$ ano do curso de Medicina - UEPG

Bolsista de Iniciação Científica - Fundação Araucária (2020-2021) 